DATA ON NATURAL ORGANIC SUBSTANCES IN DISSOLVED, COLLOIDAL, SUSPENDED-SILT, AND-CLAY AND BED-SEDIMENT PHASES IN THE MISSISSIPPI RIVER AND SOME OF ITS TRIBUTARIES, 1991-92

by J.A. Leenheer, L.B. Barber, C.E. Rostad, and T.I. Noyes

U.S. GEOLOGICAL SURVEY

Water-Resources Investigations Report 94-4191

Denver, Colorado

1995 


\section{U.S. DEPARTMENT OF THE INTERIOR BRUCE BABBITT, Secretary \\ U.S. GEOLOGICAL SURVEY \\ Gordon P. Eaton, Director}

The use of trade, product, industry, or firm names is for descriptive purposes only and does not imply endorsement by the U.S. Government.

For additional information write to:

Chief, Branch of Regional Research

U.S. Geological Survey

Box 25046, MS 418

Denver Federal Center

Denver, CO 80225
Copies of this report can be purchased from:

U.S. Geological Survey

Earth Science Information Center

Open-File Reports Section

Box 25286, MS 517

Denver Federal Center

Denver, CO 80225 


\section{CONTENTS}

Abstract

Introduction

Acknowledgments

June-August 1991 cruise

Objectives and approach

Dissolved organic matter.

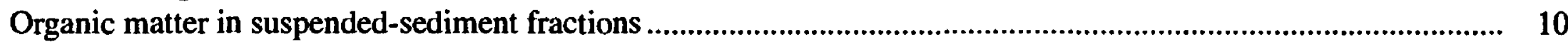

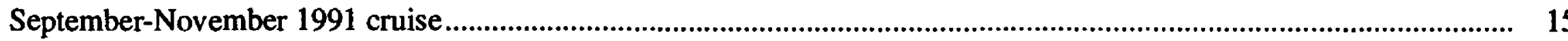

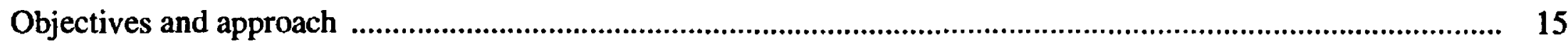

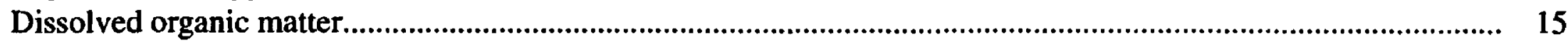

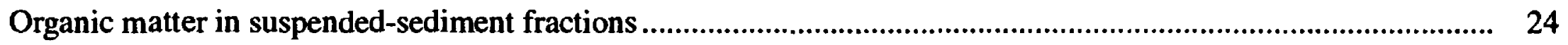

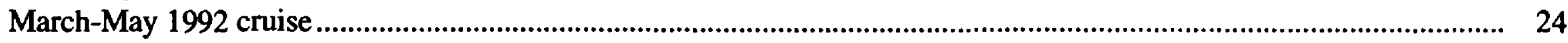

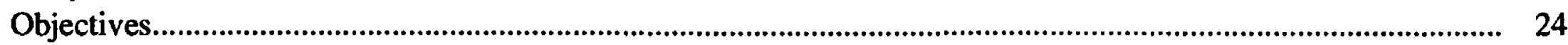

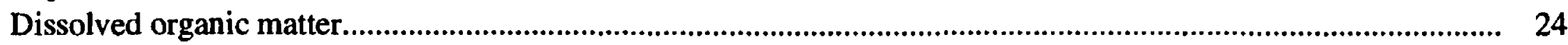

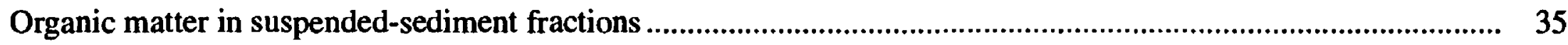

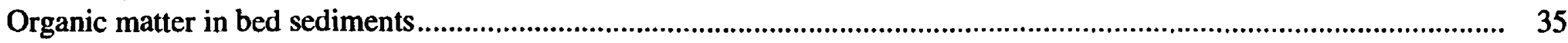

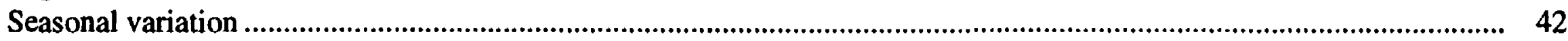

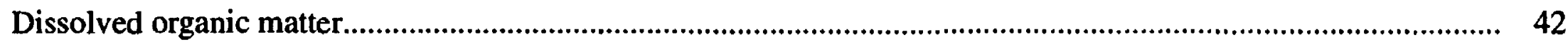

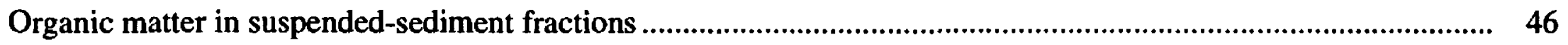

Conclusions

References cited.

\section{FIGURES}

1. Map showing location of sampling sites on the Mississippi River and some of its tributaries

2. Graphs showing dissolved organic-carbon concentration and water temperature (Moody, 1994) for the Mississippi River as a function of river miles upstream from Head of Passes, La., for the summer, fall, and spring.

3. ${ }^{1}$ H-nuclear magnetic resonance (NMR) spectrum of dissolved organic matter isolated from the Mississippi River at Hastings, Minnesota, during the April-May 1992 (spring) sampling cruise

\section{TABLES}

1. Dissolved organic-carbon concentrations for samples collected during the upriver part of the JuneAugust 1991 cruise

2. Dissolved organic-carbon concentrations and transport for samples collected during the downriver part of the June-August 1991 cruise

3. Concentrations of silt and clay and colloid fractions of suspended sediment and organic-carbon concentrations of these fractions for samples collected during the downriver part of the June-August 1991 cruise.

4. Organic-carbon and nitrogen contents of silt and clay and colloid fractions of suspended sediment for samples collected during the downriver part of the June-August 1991 cruise

5. Organic-carbon and nitrogen transport of the silt and clay and colloid fractions for sediment samples collected during the downriver part of the June-August 1991 cruise...

6. Dissolved organic-carbon concentrations for samples during the upriver part of the September-November 1991 cruise

7. Dissolved organic-carbon concentrations and transport for samples collected during the downriver part of the September-November 1991 cruise.

8. Concentrations of silt and clay and colloid fractions of suspended sediment, and organic-carbon concentrations of these fractions for samples collected during the downriver part of the SeptemberNovember 1991 cruise. 
9. Organic-carbon and nitrogen contents of silt and clay and colloid fractions of suspended sediment for samples collected during the downriver part of the September-November 1991 cruise

10. Organic-carbon and nitrogen transport of the silt and clay and colloid fractions for sediment samples collected during the downriver part of the September-November 1991 cruise.

11. Dissolved organic carbon concentrations for samples collected during the upriver part of the March-May 1992 cruise

12. Dissolved organic-carbon concentrations and transport for samples collected during the downriver part of the March-May 1992 cruise

13. Concentrations of silt and clay and colloid fractions of suspended sediment, and organic-carbon concentrations of these fractions for samples collected during the downriver part of the MarchMay 1992 cruise

14. Organic-carbon and nitrogen contents of silt and clay and colloid fractions of suspended sediment for samples collected during the downriver part of the March-May 1992 cruise

15. Organic-carbon and nitrogen transport of the silt and clay and colloid fractions for sediment samples collected during the downriver part of the March-May 1992 cruise

16. Organic-carbon and nitrogen contents of bed-sediment

17. Organic-carbon and nitrogen percentages of bed sediment samples and suspended silt and clay samples.

18. Peak height ratios for ${ }^{1} \mathrm{H}-\mathrm{NMR}$ data for dissolved organic-carbon samples collected during the September-November 1991 (fall) and March-May 1992 (spring) sampling cruises

\section{CONVERSION FACTORS AND RELATED INFORMATION}

\section{Multiply}

liter (L)

cubic meter per second $\left(\mathrm{m}^{3} / \mathrm{s}\right)$

$$
\text { kilometer }(\mathrm{km})
$$

cubic kilometers $\left(\mathrm{Km}^{3}\right)$

micrometer $(\mu \mathrm{m})$

milligrams (mg)

metric tons per day

milligrams per liter
0.2642

35.31

$0.62 / 4$

0.2399

0.00003937

0.00003527

1.102

0.0001335
To obtain

gallon

cubic foot per second

mile

cubic miles

inch

ounce, avoirdupois

short tons per day

ounce per gallon

\section{Proton Nuclear Magnetic Resonance ('H-NMR) Units}

chemical shift $[\delta$ in

Equals

chemical shift $(\tau=10-\delta)$

parts per million (ppm)]

Degree Celsius $\left({ }^{\circ} \mathrm{C}\right)$ may be converted to degree Fahrenheit $\left({ }^{\circ} \mathrm{F}\right)$ by using the following equation:

$$
{ }^{\circ} \mathrm{F}=\left(1.8 \times{ }^{\circ} \mathrm{C}\right)+32 \text {. }
$$




\title{
Data on Natural Organic Substances in Dissolved, Colloidal, Suspended-Silt and -Clay, and Bed-Sediment Phases in the Mississippi River and Some of its Tributaries: 1991-92
}

\author{
By J.A. Leenheer, L.B. Barber, C.E. Rostad, andT.I. Noyes
}

\begin{abstract}
The Mississippi River and some of its tributaries were sampled for natural organic substances dissolved in the water and in suspended and bed sediments during three sampling cruises in 1991 and 1992. Sampling for water and sediment was conducted from a research vessel from near Minneapolis, Minnesota to near New Orleans, Louisiana. Samples for dissolved organic carbon were collected as the vessel cruised upriver from New Orleans, and water and sediment samples were collected on the downriver part of the sampling cruise. The first cruise occurred during June-August, 1991; the second cruise occurred during September-November, 1991; and the third cruise occurred during March-May, 1992. The purpose for sampling and characterizing natural organic substances in the various phases in the river was to gain an understanding of how these substances facilitate contaminant transport and transformation in the Mississippi River. The study was done in cooperation with associated research projects studying transport of specific contaminants.

Significant findings of the study include the following: (1) There are large nitrogen contents (1.5 to 2.0 times normal) in the suspended and bed sediments of the Upper Mississippi River. These large nitrogen contents may cause toxic levels of ammonia resulting from microbial decomposition of nitrogen-containing organic matter in anaerobic bed sediments. (2) Organic-carbon contents of suspended colloids in the Upper Mississippi River were 2 to 3 times the organic-carbon content of suspended colloids in the Lower Mississippi River. This high organic-carbon content enhanced the transport of organic contaminants such as polychlorinated biphenyls that partition into organic matter. (3) Colloidal organic matter was transported conservatively through the navigation pools of the Upper Mississippi River. Transport calculations showed very little of the colloidal organic matter is being lost in the deeper navigation pools (Lake Pepin and Pool 19) that serve as sediment traps. (4) Organic matter in the dissolved, suspended, and colloidal phases decrease in a downstream direction. This decrease is caused by dilution by tributaries low in organic-matter concentrations and by instream losses of organic matter during transport. Evidence for instream biodegradation of organic matter was found during the summer cruise; this degradation may release bound contaminants back to the more toxic dissolved state in water.
\end{abstract}

\section{INTRODUCTION}

The Mississippi River drains about 40 percent of the conterminous United States and commonly is divided into two parts-the Lower Mississippi River and the Upper Mississippi River. Distances on the Lower Mississippi River begin at zero where the mouth of the river divides into three separate channels at Head of Passes in Louisiana and increase upstream to the mouth of the Ohio River at Cairo, Illinois (Lower Mississippi River Mile 953.8). Distances on the Upper Mississippi River begin at zero at the mouth of the Ohio River and increase upstream to the source of the Mississippi River in Minnesota (fig. 1). The Lower and Upper Mississippi Rivers are very different in hydrologic character. The Lower Mississippi River is a free flowing river, whereas about 80 percent of the navigable length of the Upper Mississippi River is controlled by a series of 29 navigation locks and dams, creating a stair-step series of navigation pools.

The mean annual water discharge of the Mississippi River increases from about $7 \mathrm{~km}^{3} / \mathrm{yr}$ near Minneapolis, Minnesota to about $500 \mathrm{~km}^{3}$ /year at Vicksburg, Mississippi (period of record 1931-1991), while the corresponding sediment discharge increases from about $0.2 \times 10^{6}$ metric tons/year to about $200 \times 10^{6}$ metric tons/year. The mean 


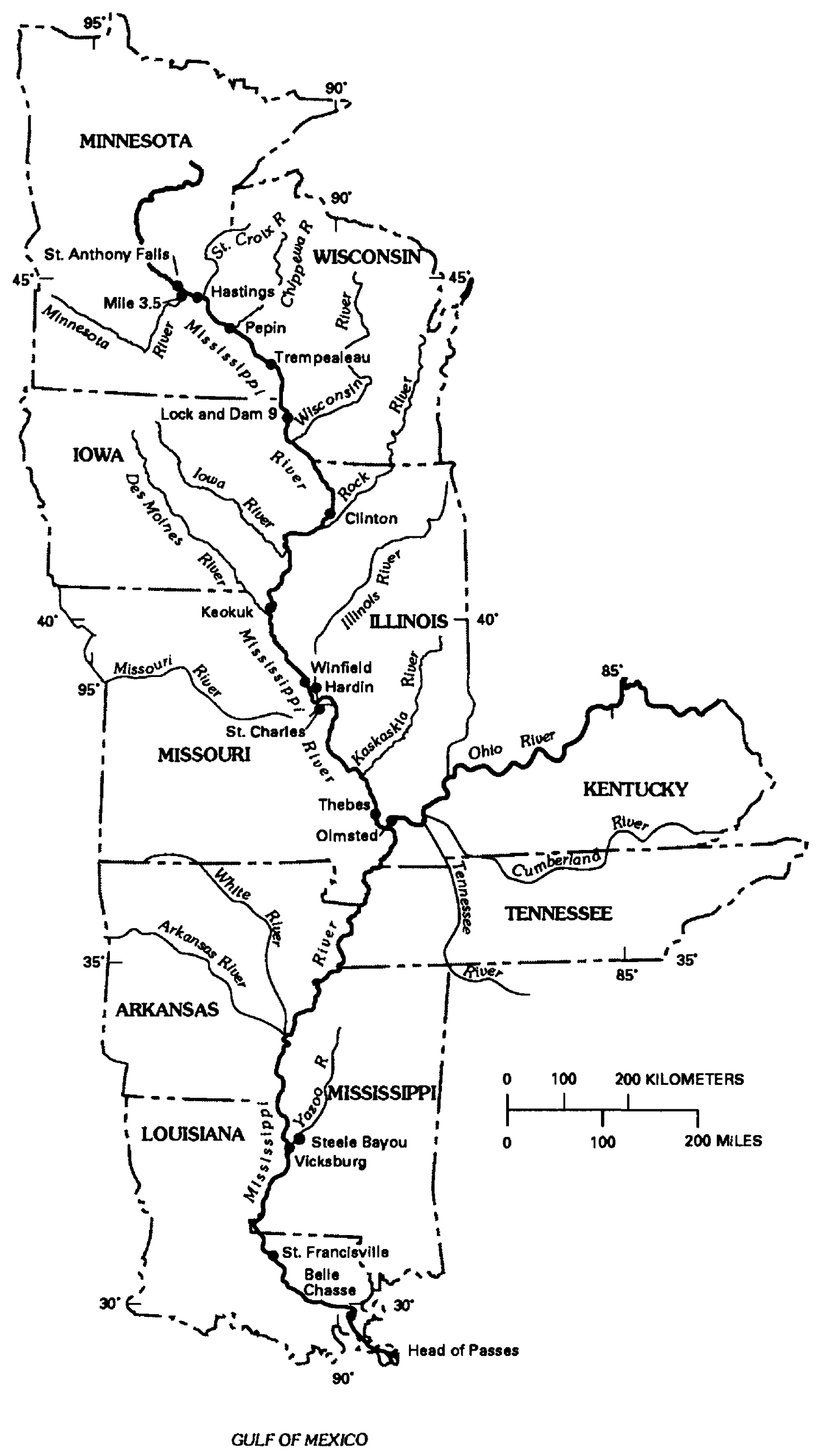

Figure 1.--Location of sampling sites on the Mississippi River and some of its tributaries. 
annual water discharge of the Mississippi River more than doubles with the addition of water from the Minnesota and St. Croix Rivers just downstream from Minneapolis, Minnesota. The mean annual discharge of the river increases slowly with each tributary input until the combined water discharges of the Illinois and Missouri Rivers more than doubles the discharge of the Upper Mississippi River to about $160 \mathrm{~km}^{3} /$ year. The addition of water from the Ohio River again doubles the discharge of the Mississippi River; both the contributions of water by the White and Arkansas Rivers (each having discharges 2 to 5 times greater than the combined flow of the Minnesota and St. Croix Rivers) only account for about 5 to 8 percent of the discharge of the Lower Mississippi River at Vicksburg, Mississippi. At 191 kilometers downstream from Vicksburg, approximately 25 percent of the water discharge and sediment discharge is diverted from the Mississippi River by the Old River control structure into the Atchafalaya River and then into the Gulf of Mexico. The remaining water $\left(375 \mathrm{~km}^{3} /\right.$ year $)$ and sediment $\left(150 \times 10^{6}\right.$ metric tons/ year) are discharged by the Mississippi River directly into the Gulf of Mexico (Moody and Meade, 1992).

Most contaminants have some degree of association with natural organic substances in the dissolved, colloidal, and particulate phases in water (Leenheer, 1991; Leenheer and others, 1994). These associations may either facilitate or retard contaminant transport in rivers and may transform contaminants into different phases or different compounds depending on the operative degradation processes. The U.S. Geological Survey began a study of contaminant assessment and transport in the Mississippi River and some of its tributaries in 1987.

This report summarizes the research on natural organic substances that was conducted during three sampling cruises on the Mississippi River between Minneapolis, Minn., and New Orleans, La., between June 1991 and May 1992. Although the sampling encompassed the entire river, the intensity of the sampling was much greater on the Upper Mississippi River upstream from St. Louis, Mo., because a previous study (Leenheer and others, 1995) performing similar research was conducted on the Lower Mississippi River from 1987-90. Integration of the research presented in this report with the research on metal and organic contaminants in the Lower Mississippi River will provide an understanding of how natural organic substances affect contaminant transport and transformations.

\section{Acknowledgments}

The data presented in this report are the result of a group effort in sampling the Mississippi River and some of its tributaries, processing the samples to fractionate and isolate the various dissolved and sediment phases, and sharing data and assisting in data interpretation.

The authors wish to acknowledge the crew of the research vessel ACADIANA-Wayne Simoneaux, Daniel Guidry, Craig LeBoeuf, Robert Cutting, Jean Hough, Elaine Robichaux, Cheryl Blanchard, George Collier, Wilton Delaune, Mike Detraz, Derral Dupre, and Jonathan Landry—who have accommodated our unusual requests and who have ensured the maintenance of proper scientific operations.

We also wish to acknowledge the Mississippi River project chief, Robert H. Meade, who along with John Moody, attempted to teach a boatload of chemists the fundamentals of surface-water hydrology.

Lastly, we wish to acknowledge our colleagues who assisted in measuring river discharge, collecting and processing large volumes of water for water and sediment sampling, performing field and laboratory measurements, and performing miscellaneous boat operations. These people include Ronald C. Antweiler, LaDonna M. Bishop, Terry I. Brinton, Gregory K. Brown, Wesley L. Campbell, Goeff S. Ellis, John R. Garbarino, Donald A. Goolsby, Heidi Hayes, Robert M. Hirsch, Donald Kelley, Jim Krest, Gail E. Mallard, Richard Martin, Stephanie G. Monsterleet, Dale B. Peart, Ronald E. Rathbun, Alan M. Shiller, John F. Sullivan, David Roth, Charles F. Tabor, Howard E. Taylor, Woodrow Wang, Harold Weigner, and Jeffrey H. Writer.

\section{JUNE-AUGUST 1991 CRUISE}

\section{Objectives and Approach}

Following are the objectives of the first sampling cruise. (1) Increase volume of water processed through the centrifuge and ultrafilter from $100 \mathrm{~L}$ used in the previous Mississippi River studies (Leenheer and others, 1989; Leenheer and others, 1995) to 500 to $1,000 \mathrm{~L}$ to obtain sufficient suspended silt, clays, and colloids for organic-car- 
bon and nitrogen analyses from the navigation pools of the Upper Mississippi River where suspended sediment concentrations are much less than in the Lower Mississippi River. (2) Obtain composite bed-sediment samples from transects across the lower portions of the navigation pools for organic-carbon and nitrogen analyses. (3) Obtain high-resolution dissolved organic-carbon (DOC) data (samples taken from midchannel approximately every $16.1 \mathrm{~km}$ ) on the upriver part of the cruise.

The water samples obtained for DOC analyses during the upriver part of the cruise were collected from just below the water surface with a stainless-steel bucket. The samples were filtered through a $1-\mu \mathrm{m}$ glass fiber filter and were preserved by refrigeration. The large-volume samples $(500$ to $1,000 \mathrm{~L})$ taken on the downriver part of the cruise were collected by pumping discharge-weighted volumes of water from $5 \mathrm{~m}$ below the surface or onehalf the water depth at 4 to 40 locations across the river and combining suspended sediments in these samples into one pumped composite sample. This pumping method was found to undersample the suspended sand $(>63 \mu \mathrm{m})$ but to collect a representative sample of the suspended silt and clay fraction $(<63 \mu \mathrm{m})$ (Moody and Meade, 1994). This sample was then sequentially passed through a sieve to separate the sand fraction, through a continuous-flow centrifuge to separate the suspended silt and clay, and finally through a tangential-flow ultrafilter to separate the colloid fraction (Leenheer and others, 1989). Silts and clays from the centrifuge and colloids from the ultrafilter were composited into separate "pumped-composite" fractions.

Some modifications were made to previous procedures (Leenheer and others, 1989) to obtain better recoveries of the silt and clay and colloid fractions. For the silt and clay fraction, the centrifuge housing of the drag bushing assembly was changed to capture the silts and clays that were previously lost to the sump of the centrifuge when the water drained from the bowl when the centrifuge was shut down. The water-collection area and drains in this housing were coated with Teflon to minimize contamination. When the centrifuge was shut down, the water that drained from the bowl was collected in a 2-L Teflon bottle, the coarse silt was allowed to settle, and the water was decanted. For the pumped composite samples, this coarse silt fraction was recombined with the silt recovered from the Teflon liner in the centrifuge bowl. The second procedure modification was to disassemble the bowl-bottom sealing unit of the centrifuge bowl and rinse out the silt and clay trapped in this unit. The third procedure modification was to place the Teflon liner from the centrifuge bowl inside a Teflon bag containing water that drained back from the centrifuge and to remove the accumulated silt and clay by massaging the liner surface with the inside of the Teflon bag. The previous procedure used a scraper to remove the silt. Finally, the silt suspension was allowed to settle for 1-2 weeks during storage at $4^{\circ} \mathrm{C}$ in the laboratory; the supernatant suspension was decanted and the silt was air dried.

For the colloid fraction, 15 ultrafilter plates were used to filter as much as $1,000 \mathrm{~L}$ of water. After removing the colloids from the ultrafilter plates by massaging the plates with retentate water inside a Teflon bag, the entire colloid suspension was concentrated in 1 to $2 \mathrm{~L}$ of retentate water. The previous procedure (Leenheer and others, 1989) used additional supercentrifugation in the laboratory to separate the colloids into a mineral colloid and an organic colloid fraction. The modified procedure freeze-dried the entire colloid suspension to obtain better recoveries.

\section{Dissolved Organic Matter}

For samples from the downriver part of the cruises, DOC concentrations were determined on a Dohrmann DC-190 carbon analyzer by high-temperature oxidation of dissolved organic carbon to carbon dioxide (Hedges and Farrington, 1993). For samples from the upriver part of the cruises, DOC concentrations were determined by persulfate oxidation of organic matter to $\mathrm{CO}_{2}$ with an Oceanographic International Model 700 carbon analyzer (Aiken, 1992). For both of these methods for the freshwater samples from the Mississippi River, DOC was quantitatively measured after compensation for the system blanks with a precision of $\pm 0.1 \mathrm{mg} / \mathrm{L}$. DOC transport for the downriver legs were computed using water-discharge measurements reported by Moody and Meade (1994b). DOC concentrations measured on samples taken during the upriver part of the cruise are presented in table 1.

The data in table 1 show that DOC is relatively low (3.6 to $5.1 \mathrm{mg} / \mathrm{L})$ and invariant in the Lower Mississippi River (river mile 0 to 954); whereas in the Upper Mississippi River (river mile 954 to 1800), the DOC a maximum of $14.4 \mathrm{mg} / \mathrm{L}$ at Minneapolis, Minn. Tributary inputs from the Ohio, Missouri, Illinois, Des Moines, Skunk, Iowa, and Minnesota Rivers dilute DOC concentrations in the Mississippi River. DOC concentrations in the Rock, Wisconsin, Black, and Chippewa Rivers are similar to DOC concentrations in the Mississippi River, and the St. Croix 
Table 1. Dissolved organic-carbon concentrations for samples collected during the upriver part of the June-August 1991 cruise

[CDT, Central Daylight Time; mg/L, milligrams per liter]

\begin{tabular}{|c|c|c|}
\hline Time (CDT) & River mile above Head of Passes, Louisiana' & $\begin{array}{l}\text { Dissolved organic carbon } \\
\text { concentratlon (mg/L) }\end{array}$ \\
\hline \multicolumn{3}{|c|}{$\begin{array}{l}\text { UPPER MISSISSIPPI RIVER } \\
\text { July 2, 1991 }\end{array}$} \\
\hline 2115 & $1,799.8$ & 14.4 \\
\hline 2058 & 1,797.8 Minnesota River & 7.3 \\
\hline 2008 & $1,791.8$ & 9.8 \\
\hline 1757 & $1,779.9$ & 10.3 \\
\hline 1614 & $1,766.2$ & 9.6 \\
\hline 1605 & 1,765.3 St. Croix River & 20.8 \\
\hline 1519 & $1,759.3$ & 10.2 \\
\hline 1154 & $1,730.2$ & 10.9 \\
\hline 1049 & $1,718.7$ & 11.8 \\
\hline 1035 & 1,717.2 Chippewa River & 12.4 \\
\hline 0939 & $1,709.3$ & 11.9 \\
\hline 0535 & $1,689.5$ & 12.1 \\
\hline 0347 & $1,677.0$ & 11.6 \\
\hline 0133 & $1,663.8$ & 12.3 \\
\hline \multicolumn{3}{|c|}{ July 1, 1991} \\
\hline 2359 & 1,652.0 Black River & 12.8 \\
\hline 2238 & $1,639.9$ & 11.6 \\
\hline 2123 & $1,629.3$ & 11.6 \\
\hline 2014 & $1,618.5$ & 12.2 \\
\hline 1855 & $1,606.8$ & 12.1 \\
\hline 1735 & $1,595.6$ & 11.6 \\
\hline 1634 & $1,586.8$ & 12.4 \\
\hline 1614 & 1,584.4 Wisconsin River & 9.9 \\
\hline 1329 & $1,563.8$ & 11.4 \\
\hline 1145 & $1,556.0$ & 11.3 \\
\hline 1030 & $1,544.3$ & 11.4 \\
\hline 0914 & $1,535.3$ & 11.3 \\
\hline 0813 & $1,525.8$ & 11.1 \\
\hline 0700 & $1,514.5$ & 11.2 \\
\hline 0555 & $1,504.8$ & 10.8 \\
\hline 0440 & $1,493.6$ & 10.5 \\
\hline 0340 & $1,484.8$ & 10.5 \\
\hline 0204 & $1,473.8$ & 10.3 \\
\hline 0056 & $1,463.1$ & 10.2 \\
\hline
\end{tabular}


Table 1. Dissolved organic-carbon concentrations for samples collected during the upriver part of the June-August 1991 cruise --Continued

\begin{tabular}{|c|c|c|}
\hline Time (CDT) & River mile above Head of Passes, Louisiana ${ }^{1}$ & $\begin{array}{l}\text { Dissoived organic carbon } \\
\text { concentration (mg/L) }\end{array}$ \\
\hline \multicolumn{3}{|c|}{$\begin{array}{l}\text { UPPER MISSISSIPPI RIVER-Continued } \\
\text { Juue 30, } 1991\end{array}$} \\
\hline 2355 & $1,454.8$ & 9.9 \\
\hline 2219 & $1,444.9$ & 9.9 \\
\hline 2046 & $1,433.8$ & 9.8 \\
\hline 2035 & 1,432.8 Rock River & 9.9 \\
\hline 1842 & $1,410.9$ & 9.3 \\
\hline 1613 & $1,401.4$ & 9.2 \\
\hline 1349 & 1,387.8 Iowa River & 4.3 \\
\hline 1139 & $1,371.0$ & 8.6 \\
\hline 0620 & $1,356.6$ & 8.6 \\
\hline 0533 & 1,349.6 Skunk River & 3.0 \\
\hline 0405 & $1,335.6$ & 7.8 \\
\hline 0302 & $1,324.7$ & 8.5 \\
\hline 0123 & $1,317.7$ & 7.4 \\
\hline 0111 & 1,315.2 Des Moines River & 4.3 \\
\hline \multicolumn{3}{|c|}{ June 29, 1991} \\
\hline 2312 & $1,295.3$ & 6.4 \\
\hline 2120 & $1,284.8$ & 6.9 \\
\hline 1959 & $1,274.8$ & 7.5 \\
\hline 1842 & $1,263.8$ & 7.4 \\
\hline 1701 & $1,252.8$ & 6.9 \\
\hline 1606 & $1,244.8$ & 6.4 \\
\hline 1514 & $1,237.1$ & 7.2 \\
\hline 1257 & $1,225.8$ & 6.8 \\
\hline 1145 & $1,214.0$ & 6.5 \\
\hline 1026 & $1,203.0$ & 6.6 \\
\hline 0915 & $1,194.0$ & 6.3 \\
\hline 0802 & $1,183.0$ & 6.4 \\
\hline 0709 & $1,175.4$ & 6.8 \\
\hline 0550 & 1,171.7 Illinois River & 4.7 \\
\hline 0012 & $1,161.0$ & 6.5 \\
\hline \multicolumn{3}{|c|}{ June 28, 1991} \\
\hline 2245 & $1,152.2$ & 6.0 \\
\hline 1945 & 1,149.1 Missouri River & 3.6 \\
\hline 1832 & $1,134.1$ & 6.2 \\
\hline 1706 & $1,123.8$ & 4.5 \\
\hline 1541 & $1,112.0$ & 6.1 \\
\hline
\end{tabular}


Table 1. Dissolved organic-carbon concentrations for samples collected during the upriver part of the June-August 1991 cruise --Continued

\begin{tabular}{|c|c|c|}
\hline Time (CDT) & Rlver mile above Head of Passes, Louisiana' & $\begin{array}{l}\text { Dissoived organic carbon } \\
\text { concentration (mg/L) }\end{array}$ \\
\hline \multicolumn{3}{|c|}{ UPPER MISSISSIPPI RIVER-Continued } \\
\hline \multicolumn{3}{|c|}{ June 28, 1991-Continued } \\
\hline 1437 & $1,103.8$ & 5.4 \\
\hline 1321 & $1,094.2$ & 4.7 \\
\hline 1205 & $1,084.4$ & 5.3 \\
\hline 1045 & $1,073.9$ & 5.1 \\
\hline 0928 & $1,063.8$ & 5.6 \\
\hline 0814 & $1,054.5$ & 5.3 \\
\hline 0702 & $1,044.8$ & 5.1 \\
\hline 0603 & $1,036.6$ & 5.1 \\
\hline 0452 & $1,027.5$ & 5.2 \\
\hline 0334 & $1,017.1$ & 5.2 \\
\hline 0214 & $1,005.4$ & 5.4 \\
\hline 0024 & 992.8 & 5.1 \\
\hline \multicolumn{3}{|c|}{ June 27, 1991} \\
\hline 2304 & 983.4 & 5.2 \\
\hline 2154 & 974.7 & 5.1 \\
\hline 2034 & 964.6 & 5.2 \\
\hline 1903 & 953.8 Ohio River & 2.5 \\
\hline \multicolumn{3}{|c|}{$\begin{array}{l}\text { LOWER MISSISSIPPI RIVER } \\
\text { June 27, } 1991\end{array}$} \\
\hline 1553 & 937.6 & 4.4 \\
\hline 1418 & 924.5 & 4.4 \\
\hline 1255 & 911.9 & 4.3 \\
\hline 1118 & 898.9 & 4.8 \\
\hline 1017 & 890.5 & 4.3 \\
\hline 0919 & 882.4 & 4.6 \\
\hline 0757 & 870.0 & 4.5 \\
\hline 0653 & 860.2 & 4.7 \\
\hline 0525 & 848.5 & 4.4 \\
\hline 0403 & 839.0 & 4.6 \\
\hline 0324 & 835.5 & 4.7 \\
\hline 0221 & 826.7 & 5.1 \\
\hline 0105 & 817.5 & 4.5 \\
\hline \multicolumn{3}{|c|}{ June 26, 1991} \\
\hline 2345 & 807.9 & 4.6 \\
\hline 2224 & 797.4 & 4.5 \\
\hline 2042 & 785.0 & 4.5 \\
\hline 1919 & 773.0 & 4.4 \\
\hline 1802 & 762.2 & 4.7 \\
\hline
\end{tabular}


Table 1. Dissolved organic-carbon concentrations for samples collected during the upriver part of the June-August 1991 cruise --Continued

\begin{tabular}{|c|c|c|}
\hline Time (CDT) & River mlle above Head of Passes, Louisisna ${ }^{1}$ & $\begin{array}{l}\text { Dissolved orgsnic csrbon } \\
\text { concentration (mg/L) }\end{array}$ \\
\hline \multirow{2}{*}{\multicolumn{3}{|c|}{$\begin{array}{l}\text { LOWER MISSISSIPPI RIVER-Continned } \\
\text { June 26, 1991-Continned }\end{array}$}} \\
\hline & & \\
\hline 1640 & 751.1 & 4.5 \\
\hline 1525 & 742.0 & 4.3 \\
\hline 1248 & 731.5 & 4.4 \\
\hline 1135 & 721.5 & 4.5 \\
\hline 1023 & 712.9 & 4.4 \\
\hline 0903 & 702.0 & 4.3 \\
\hline 0725 & 689.9 & 4.4 \\
\hline 0616 & 680.0 & 4.6 \\
\hline 0505 & 669.9 & 4.4 \\
\hline 0353 & 660.2 & 4.5 \\
\hline 0241 & 650.2 & 4.4 \\
\hline 0113 & 639.7 & 4.4 \\
\hline \multicolumn{3}{|c|}{ June 25, 1991} \\
\hline 2314 & 629.3 & 4.4 \\
\hline 2223 & 616.5 & 4.4 \\
\hline 2109 & 610.0 & 4.3 \\
\hline 1932 & 600.2 & 4.3 \\
\hline 1834 & 590.3 & 4.2 \\
\hline 1718 & 580.8 & 4.2 \\
\hline 1635 & 575.0 & 4.1 \\
\hline 1528 & 562.2 & 4.0 \\
\hline 1420 & 552.5 & 4.1 \\
\hline 1310 & 545.0 & 4.0 \\
\hline 1106 & 534.5 & 4.0 \\
\hline 1000 & 525.3 & 4.0 \\
\hline 0837 & 514.1 & 4.1 \\
\hline 0725 & 504.5 & 4.0 \\
\hline 0618 & 493.0 & 4.0 \\
\hline 0512 & 485.5 & 4.0 \\
\hline 0400 & 475.0 & 4.1 \\
\hline 0315 & 469.0 & 4.0 \\
\hline 0215 & 460.8 & 4.0 \\
\hline 0050 & 449.1 & 4.2 \\
\hline
\end{tabular}


Table 1. Dissolved organic-carbon concentrations for samples collected during the upriver part of the June-August 1991 cruise --Continued

\begin{tabular}{ccc}
\hline Time (CDT) & River mile above Hoad of Passes, Louisiana ${ }^{1}$ & $\begin{array}{c}\text { Dissoived organic carbon } \\
\text { concentration (mg/L) }\end{array}$ \\
\hline & LOWER MISSISSIPPI RIVER-Continued \\
2352 & $\begin{array}{c}\text { Jnne 24, 1991 } \\
2259\end{array}$ & 4.0 \\
2135 & 432.0 & 3.9 \\
2029 & 420.1 & 4.0 \\
1915 & 409.5 & 4.0 \\
& 399.4 & 4.0 \\
1810 & & \\
1704 & 389.8 & 4.1 \\
1605 & 380.4 & 4.1 \\
1320 & 371.2 & 3.9 \\
1215 & 360.0 & 4.0 \\
& 351.2 & 3.8 \\
1105 & & \\
1010 & 340.0 & 3.8 \\
0833 & 330.4 & 3.9 \\
0745 & 320.0 & 3.8 \\
0640 & 310.0 & 3.8 \\
& 300.0 & 3.7 \\
0525 & & \\
0415 & 289.8 & 3.6 \\
0300 & 279.7 & 3.8 \\
0146 & 269.6 & 3.9 \\
0045 & 258.6 & 3.9 \\
2345 & 248.8 & 3.9 \\
2240 & June 23, 1991 & 4.0 \\
\hline
\end{tabular}

To obtain Upper Mississippi River miles, subtract 953.8 from all river miles greater than 953.8. Tributary locations are Mississippi River miles at mouths of tributaries. 
River has DOC concentrations substantially in excess of DOC found in the Mississippi River. No DOC peaks indicative of large, organic contamination inputs are shown in table 1 data.

Data collected on the downriver part of the sampling cruise had more significance with regard to transport than the upriver part data because depth-integrated sampling was proportional to the water discharge, although sampling in the strict Lagrangian sense was not attempted and evaluated. The samples were also more representative because of the depth integration. The concentration and transport of DOC for the downstream part of the July-August 1991 cruise are given in table 2.

The water discharge data in table 2 indicates no substantial gains or losses at tributary confluences until the diversion of the Old River downstream from Vicksburg, Mississippi; thus, sampling likely occurred with reasonable adherence to Lagrangian conditions. The data in table 2 indicate a possible instream loss of DOC in the Upper Mississippi River, but no significant DOC loss in the Lower Mississippi River. This cumulative loss reaches a maximum at the Keokuk, Iowa, sampling site. The dissolved organic-carbon concentrations listed in table 2 are slightly less than those listed in table 1 . These lower concentrations may result from the sample being ultrafiltered because ultrafiltration removes 10-15 percent of the DOC as colloids (Leenheer and others, 1995). It is also likely that DOC concentrations changed between the upriver and downriver legs of the sampling cruises.

\section{Organic Matter in Suspended-Sediment Fractions}

Concentrations of silt and clay and colloids were determined by physically isolating, weighing, and analyzing these fractions recovered from very large volumes of water $(500$ to $1000 \mathrm{~L})$ passed through the continuousflow centrifuge and ultrafilter. Organic-carbon and nitrogen analyses were performed on the recovered fractions by Huffman Laboratories, Inc., Golden, Colo. Organic carbon was determined as the difference between total carbon and carbonate carbon. Nitrogen was determined as total nitrogen that included both ammonium and organic forms of nitrogen. The maximum relative standard deviation allowed by the laboratory for replicate sediment samples was 10 percent for organic carbon and 20 percent for nitrogen. Computed concentrations for silt and clay, colloid, silt and clay organic carbon, and colloidal organic carbon are presented in table 3.

Recovery of the silt and clay plus colloid fractions ranged from 78 to 102 percent. These recoveries are defined as the concentration of the silt and clay and colloid fractions calculated for the pumped-composite sample divided by the concentration calculated for the $<63-\mu \mathrm{m}$ sediment fraction (Moody and Meade, 1994b) for the depth-integrated composite sample times 100 . Sediment losses result from undersampling the coarse silt fraction with the pump sampler, losses during cleaning of the centrifuge and ultrafilter, loss from the centrifuge during the centrifuge shutdown procedure, and laboratory losses during the final drying and weighing procedure. Silt and clay concentrations vary with suspended sediment concentrations, but colloid and especially colloidal organic-carbon concentrations are relatively constant. Even the silt and clay organic-carbon concentration varies much less than the silt and clay concentration. Decreases in the silt and clay concentrations at the Pepin, Wis., and Keokuk, Iowa, sites illustrate how Lake Pepin and Pool 19 act as suspended-sediment traps.

Colloid organic-carbon concentrations that are initially $1.1 \mathrm{mg} / \mathrm{L}$ at the St. Anthony Falls, Minn., site decrease to $0.7 \mathrm{mg} / \mathrm{L}$ at the Trempealeau, Wis., site because of dilution by waters of lower colloid concentration from the Minnesota, St. Croix, and Chippewa Rivers, and then increase downriver to a maximum $(0.9 \mathrm{mg} / \mathrm{L})$ at the Keokuk, Iowa, site. The decrease in colloid organic-carbon concentrations downriver to Belle Chasse, La., results from dilution from tributaries and possible instream degradation of colloidal organic carbon. The instream degradation hypothesis is supported by colloidal organic-carbon concentration decreases at the last three sampling sites in the Lower Mississippi River where there are no significant tributary inputs to cause dilution. Salt flocculation of colloids is not a factor for this data set because these Lower Mississippi River samples were taken above the salinity gradient.

The organic-carbon and nitrogen contents of the silt and clay and colloid fractions are listed in table 4. The results are given on a dry-weight percent basis.

The organic-carbon content of the colloid fraction is three to five times as great as that of the silt and clay fraction. This feature of colloids is very important with regard to contaminant transport of nonpolar organic contaminants such as polychlorinated biphenyls (PCB's) that partition into the organic matter (Rostad and others, 1994). The greatest organic-carbon percentages on the silts and clays and colloids were recorded at sites where suspended-sediment concentrations were low. There appears to be a fractionation whereby low organic-carbon 
Table 2. Dissolved organic-carbon concentrations and transport for samples collected during the downriver part of the JuneAugust 1991 cruise

[mg/L, milligram per liter; $\mathrm{m}^{3} / \mathrm{s}$, cubic meter per second; --, site not directly below a tributary; ]

\begin{tabular}{|c|c|c|c|c|c|c|c|}
\hline \multirow[b]{2}{*}{$\begin{array}{l}\text { Date } \\
1991\end{array}$} & \multirow[b]{2}{*}{ Site name } & \multirow{2}{*}{$\begin{array}{c}\text { Rlver mlie } \\
\text { above } \\
\text { Head } \\
\text { of Passes, } \\
\text { Loulslana" }\end{array}$} & \multirow{2}{*}{$\begin{array}{c}\text { Water } \\
\text { dlscharge } \\
\left(\mathrm{m}^{3} / \mathrm{s}\right)\end{array}$} & \multirow{2}{*}{$\begin{array}{c}\text { Dissolved } \\
\text { organic } \\
\text { carbon } \\
\text { concentratlon } \\
\text { (mg/L) }\end{array}$} & \multirow{2}{*}{$\begin{array}{c}\text { Transport } \\
\text { of } \\
\text { dissolved } \\
\text { carbon } \\
\text { (metric } \\
\text { tons per } \\
\text { dey) }\end{array}$} & \multicolumn{2}{|c|}{$\begin{array}{l}\text { Cumulative percent galn } \\
\text { or loss below trlbutary }\end{array}$} \\
\hline & & & & & & $\begin{array}{c}\text { Water } \\
\text { discharga }\end{array}$ & $\begin{array}{l}\text { Carbon } \\
\text { transport }\end{array}$ \\
\hline $7-05$ & $\begin{array}{l}\text { Mississippi River above } \\
\text { St. Anthony Falls, Minn. }\end{array}$ & $1,811.5$ & 470 & 11.2 & 455 & - & -- \\
\hline $7-06$ & $\begin{array}{l}\text { Minnesota River at } \\
\text { Mile 3.5, Minn. }\end{array}$ & $1,797.8$ & 600 & 6.6 & 340 & -- & -- \\
\hline $7-08$ & $\begin{array}{l}\text { Mississippi River at } \\
\text { Hastings, Minn. }\end{array}$ & $1,766.0$ & 980 & 9.1 & 770 & -8 & -3 \\
\hline $7-08$ & $\begin{array}{l}\text { St. Croix River at } \\
\text { Mile } 0.5 \text {, Wis. }\end{array}$ & $1,765.3$ & 260 & 13.5 & 303 & -- & -- \\
\hline $7-10$ & $\begin{array}{l}\text { Mississippi River near } \\
\text { Pepin, Wis. }\end{array}$ & $1,718.3$ & 1,340 & 9.0 & 1,040 & +1 & -5 \\
\hline $7-10$ & $\begin{array}{l}\text { Chippewa River at } \\
\text { Mile 1.7, Wis. }\end{array}$ & $1,717.2$ & 170 & 9.8 & 140 & -- & -- \\
\hline $7-12$ & $\begin{array}{l}\text { Mississippi River at } \\
\text { Trempealeau, Wis. }\end{array}$ & $1,667.6$ & 1,440 & 8.6 & 1,100 & -4 & -11 \\
\hline $7-15$ & $\begin{array}{l}\text { Mississippi River below } \\
\text { Lock and Dam 9, Wis. }\end{array}$ & $1,593.5$ & 1,590 & 7.8 & 1,100 & +6 & -11 \\
\hline $7-15$ & $\begin{array}{l}\text { Wisconsin River at } \\
\text { Mile 1.0, Wisconsin }\end{array}$ & $1,584.4$ & 145 & 7.2 & 90 & -- & -- \\
\hline $7-18$ & $\begin{array}{l}\text { Mississippi River at } \\
\text { Clinton, Iowa }\end{array}$ & $1,474.1$ & 1,850 & 7.7 & 1,230 & +12 & -7 \\
\hline $7-20$ & Rock River at Mile 1.0, 111. & $1,432.8$ & 70 & 4.0 & 24 & -- & -- \\
\hline $7-20$ & $\begin{array}{l}\text { Iowa River at Mile 1.0, } \\
\text { Iowa }\end{array}$ & $1,387.8$ & 200 & 2.9 & 50 & -- & -- \\
\hline $7-21$ & $\begin{array}{l}\text { Mississippi River at } \\
\text { Keokuk, Iowa }\end{array}$ & $1,316.9$ & 2,050 & 6.7 & 1,190 & +7 & -15 \\
\hline $7-22$ & $\begin{array}{l}\text { Des Moines River at } \\
\text { Mile 1.0, Iowa }\end{array}$ & $1,315.2$ & 620 & 3.8 & 200 & -- & -- \\
\hline $7-24$ & $\begin{array}{l}\text { Mississippi River near } \\
\text { Winfield, Mo. }\end{array}$ & $1,193.0$ & 2,730 & 6.2 & 1,460 & +8 & -9 \\
\hline $7-25$ & $\begin{array}{l}\text { Illinois River at } \\
\text { Hardin, Ill., Mile } 21.8\end{array}$ & $1,171.7$ & 260 & 4.1 & 92 & -- & -- \\
\hline $7-27$ & $\begin{array}{l}\text { Missouri River at } \\
\text { St. Charles, Mo., Mile } 28.4\end{array}$ & $1,149.1$ & 1,100 & 2.9 & 280 & -- & -. \\
\hline $7-28$ & $\begin{array}{l}\text { Kaskaskia River at } \\
\text { Mile 1.5, 111., Mile } 21.8\end{array}$ & $1,071.1$ & 7 & 5.1 & 3 & -- & -- \\
\hline
\end{tabular}


Table 2. Dissolved organic-carbon concentrations and transport for samples collected during the downriver part of the JuneAugust 1991 cruise --Continued

\begin{tabular}{|c|c|c|c|c|c|c|c|}
\hline \multirow[b]{2}{*}{$\begin{array}{l}\text { Date } \\
1991\end{array}$} & \multirow[b]{2}{*}{ Site name } & \multirow{2}{*}{$\begin{array}{c}\text { River mlle } \\
\text { above } \\
\text { Head } \\
\text { of Passes, } \\
\text { Louislana1 }\end{array}$} & \multirow{2}{*}{$\begin{array}{c}\text { Water } \\
\text { discharge } \\
\left(\mathrm{m}^{3} / \mathrm{s}\right)\end{array}$} & \multirow{2}{*}{$\begin{array}{c}\text { Dissoived } \\
\text { organic } \\
\text { carbon } \\
\text { concentration } \\
(m g / L)\end{array}$} & \multirow{2}{*}{$\begin{array}{c}\text { Transport } \\
\text { of } \\
\text { dissolved } \\
\text { carbon } \\
\text { (metrlc } \\
\text { tons per } \\
\text { day) }\end{array}$} & \multicolumn{2}{|c|}{$\begin{array}{l}\text { Cumulative percent gain } \\
\text { or loss below trlbutary }\end{array}$} \\
\hline & & & & & & $\begin{array}{c}\text { Water } \\
\text { dlscharge }\end{array}$ & $\begin{array}{l}\text { Carbon } \\
\text { transport }\end{array}$ \\
\hline $7-29$ & $\begin{array}{l}\text { Mississippi River at } \\
\text { Thebes, Ill. }\end{array}$ & 997.7 & 4,390 & 5.4 & 2,050 & +13 & +4 \\
\hline 7-30 & Ohio River at Olmsted, ill. & 953.8 & 2,410 & 2.0 & 420 & -- & -- \\
\hline $8-01$ & $\begin{array}{l}\text { White River at } \\
\text { Mile } 1.2 \text {, Ark. }\end{array}$ & 598.0 & 370 & 1.8 & 58 & - & -- \\
\hline $8-01$ & $\begin{array}{l}\text { Arkansas River at } \\
\text { Mile 0.0, Ark. }\end{array}$ & 581.0 & 480 & 3.6 & 150 & - & -- \\
\hline 8-02 & $\begin{array}{l}\text { Yazoo River at } \\
\text { Mile 3.0, Miss. }\end{array}$ & 437.0 & 640 & 3.4 & 190 & -- & -- \\
\hline 8.03 & $\begin{array}{l}\text { Mississippi River below } \\
\text { Vicksburg, Miss. }\end{array}$ & 433.4 & 8,750 & 3.6 & 2,720 & 12 & -3 \\
\hline 8.05 & $\begin{array}{l}\text { Mississippi River near } \\
\text { St. Francisville, La. }\end{array}$ & 266.4 & 6,190 & 3.9 & 2,090 & $-21^{3}$ & $-25^{3}$ \\
\hline $8-07$ & $\begin{array}{l}\text { Mississippi River below } \\
\text { Belle Chasse, La. }\end{array}$ & 73.1 & 4,340 & 3.8 & 1,420 & $-44^{3}$ & $-49^{3}$ \\
\hline
\end{tabular}

Tributary locations are Mississippi River miles at mouth of tributary.

${ }^{2}$ This value is the water discharge or carbon transport divided by the sum of all the inputs from tributaries upstream and Mississippi River above St. Anthony Falls, times 100.

${ }^{3}$ Flow diversion to the Old River is responsible for the cumulative percentage change. 
Table 3. Concentrations of silt and clay and colloid fractions of suspended sediment and organic carbon concentrations of these fractions in samples collected during the downiver part of the June-August 1991 cruise

[Suspended sediment concentrations are reported by Moody and Meade (1994b); <, less than; $\mu \mathrm{m}$, micrometer; mg/L, milligram per liter]

\begin{tabular}{|c|c|c|c|c|c|c|c|c|}
\hline \multirow{2}{*}{$\begin{array}{l}\text { Dete } \\
1991\end{array}$} & \multirow[t]{2}{*}{ Site name } & \multirow{2}{*}{$\begin{array}{l}\text { River mile } \\
\text { above Head } \\
\text { of Passes, } \\
\text { Loulslana' }\end{array}$} & \multirow{2}{*}{$\begin{array}{c}\text { Suspended } \\
\text { sediment } \\
\text { concentration } \\
<63 \mu \mathrm{m} \\
(\mathrm{mg} / \mathrm{L})\end{array}$} & \multicolumn{2}{|c|}{$\begin{array}{l}\text { Concentrations of } \\
\text { recovered } \\
\text { sediment frections }\end{array}$} & \multirow{2}{*}{$\begin{array}{l}\text { Recovery } \\
\text { of silt } \\
\text { and clay } \\
\text { and } \\
\text { collold } \\
\text { (percent) }\end{array}$} & \multicolumn{2}{|c|}{$\begin{array}{l}\text { Concentrations of } \\
\text { organic cerbon of } \\
\text { recovered } \\
\text { sediment fractions }\end{array}$} \\
\hline & & & & $\begin{array}{l}\text { Slit end } \\
\text { clay } \\
\text { (mg/L) }\end{array}$ & $\begin{array}{l}\text { Collold } \\
\text { (mg/L) }\end{array}$ & & $\begin{array}{l}\text { Silt end } \\
\text { clay } \\
\text { (mg/L) }\end{array}$ & $\begin{array}{l}\text { Colloid } \\
\text { (mgh) }\end{array}$ \\
\hline $7-05$ & $\begin{array}{l}\text { Mississippi River above } \\
\text { St. Anthony Falls, Minn. }\end{array}$ & $1,811.5$ & 30 & 24.8 & 4.1 & 96 & 1.8 & 1.1 \\
\hline $7-06$ & $\begin{array}{l}\text { Minnesota River at } \\
\text { Mile 3.5, Minn. }\end{array}$ & $1,797.8$ & 103 & 80.4 & 5.8 & 84 & 2.3 & ${ }^{2} 0.6$ \\
\hline $7-08$ & $\begin{array}{l}\text { Mississippi River at } \\
\text { Hastings, Minn. }\end{array}$ & $1,766.0$ & 82 & 66.1 & 5.5 & 87 & 2.4 & 0.9 \\
\hline $7-10$ & $\begin{array}{l}\text { Mississippi River near } \\
\text { Pepin, Wis. }\end{array}$ & $1,718.3$ & 9 & 5.6 & 3.2 & 98 & 0.5 & 0.7 \\
\hline $7-12$ & $\begin{array}{l}\text { Mississippi River at } \\
\text { Trempealeau, Wis. }\end{array}$ & $1,667.6$ & 28 & 19.7 & 2.7 & 80 & 1.1 & 0.7 \\
\hline $7-15$ & $\begin{array}{l}\text { Mississippi River below } \\
\text { Lock and Dam 9, Wis. }\end{array}$ & $1,593.5$ & 73 & 60.1 & 4.2 & 88 & 2.6 & 0.8 \\
\hline $7-18$ & $\begin{array}{l}\text { Mississippi River at } \\
\text { Clinton, lowa }\end{array}$ & $1,474.1$ & 66 & 53.9 & 3.8 & 87 & 2.4 & 0.9 \\
\hline $7-21$ & $\begin{array}{l}\text { Mississippi River at } \\
\text { Keokuk, Iowa }\end{array}$ & $1,316.9$ & 45 & 34.7 & 3.8 & 86 & 1.9 & 0.9 \\
\hline 7.24 & $\begin{array}{l}\text { Mississippi River near } \\
\text { Winfield, Mo. }\end{array}$ & $1,193.0$ & 74 & 58.9 & 4.3 & 85 & 3.4 & 0.7 \\
\hline $7-25$ & $\begin{array}{l}\text { Illinois River at } \\
\text { Hardin, Ill. }\end{array}$ & $1,171.7$ & 47 & 42.9 & 4.9 & 102 & 1.3 & 0.8 \\
\hline $7-27$ & $\begin{array}{l}\text { Missouri River at } \\
\text { St. Charles, Mo. }\end{array}$ & $1,149.1$ & 108 & 95.6 & 5.1 & 93 & 2.1 & 0.4 \\
\hline $7-29$ & $\begin{array}{l}\text { Mississippi River at } \\
\text { Thebes, Ill. }\end{array}$ & 997.7 & 82 & 67.7 & 4.8 & 88 & 2.0 & 0.6 \\
\hline $7-30$ & $\begin{array}{l}\text { Ohio River at } \\
\text { Olmsted, III. }\end{array}$ & 953.8 & 22 & 14.5 & 2.6 & 78 & 0.6 & 0.6 \\
\hline $8-03$ & $\begin{array}{l}\text { Mississippi River below } \\
\text { Vicksburg, Miss. }\end{array}$ & 433.4 & 108 & 92.8 & 4.9 & 90 & 1.9 & 0.4 \\
\hline $8-05$ & $\begin{array}{l}\text { Mississippi River near } \\
\text { St. Francisville, La. }\end{array}$ & 266.4 & 112 & 95.4 & 4.6 & 89 & 1.8 & 0.4 \\
\hline $8-07$ & $\begin{array}{l}\text { Mississippi River below } \\
\text { Belle Chasse, La. }\end{array}$ & 73.1 & 42 & 31.5 & 3.1 & 82 & 0.8 & 0.2 \\
\hline
\end{tabular}


Table 4. Organic-carbon and nitrogen contents of silt and clay and colloid fractions of suspended sediment in samples collected during the downriver part of the June-August 1991 cruise

[C, carbon; $N$, nitrogen]

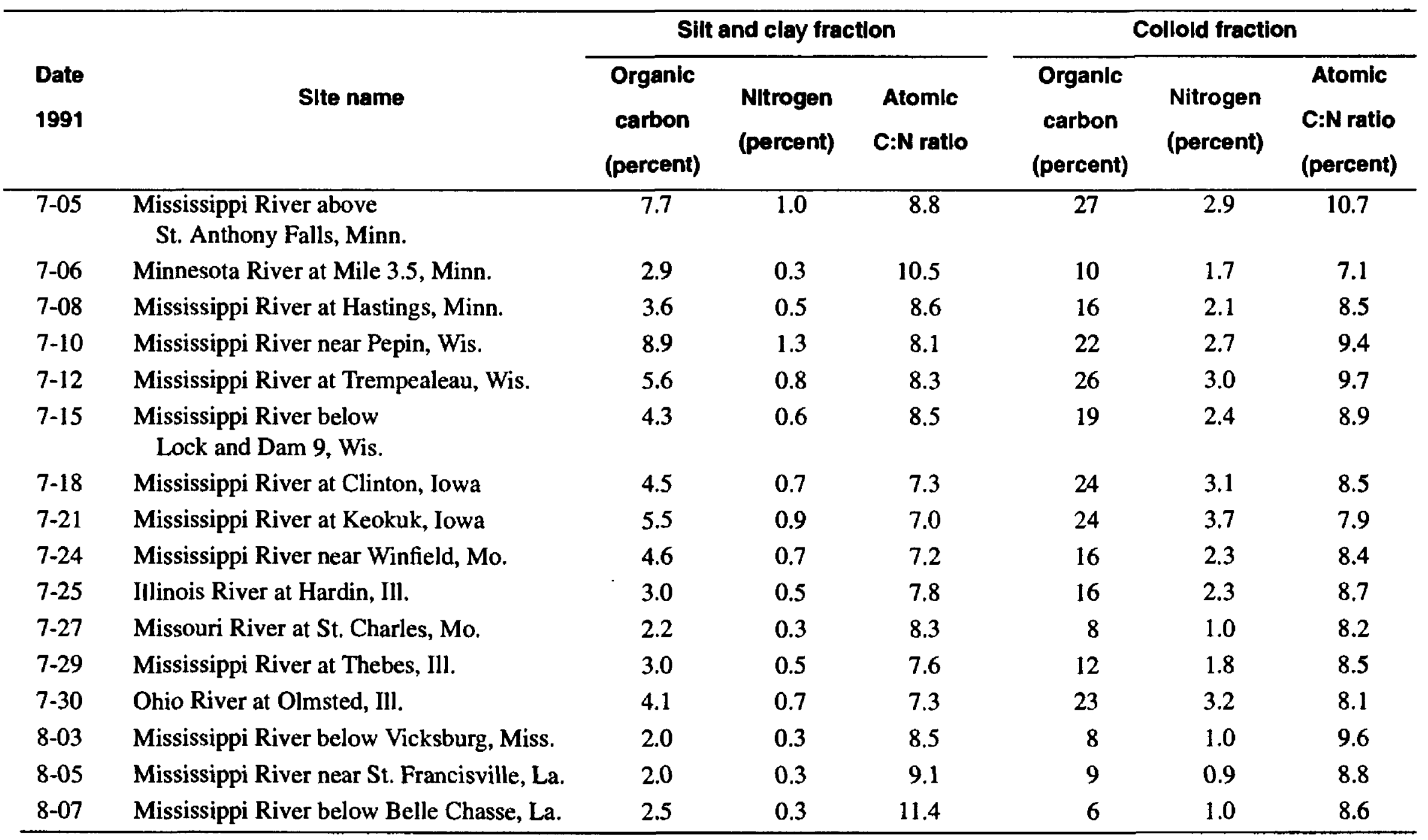


clay colloids flocculated into silt-sized aggregates and are removed by sedimentation processes. Organic matter is known to disperse clay colloids so that they do not flocculate into larger particles (Frenkel and others, 1992).

In the lower Mississippi River, instream degradation of organic matter on the silt and colloid fractions might be indicated by decreasing carbon contents and increasing ratios of carbon to nitrogen. However, inputs of lowcarbon sediments from the Missouri River and the analytical errors associated with the nitrogen determination may be alternative explanations for these observed changes in the lower Mississippi River.

The data in tables 3 and 4 were used to calculate transport of organic carbon and nitrogen in the silt and colloidal phases. These results are shown in table 5.

Major transport of organic carbon and nitrogen on the silt and clay fraction came from the Des Moines and Arkansas Rivers. However, most of this transport was lost, apparently by sedimentation and instream degradation of organic matter, by the time the river passed Belle Chasse, La. Further measurements are necessary to verify the hypothesis about instream degradation of organic matter during transport because the river was not sampled in a perfect Lagrangian manner during the downriver cruises.

A major portion of the colloid organic-carbon and nitrogen transport in the Upper Mississippi River is in the reach between Trempealeau, Wis., and Winfield, Mo. Where sediment concentrations are low (Mississippi River near Pepin, Wis., and the Ohio River at Olmsted, Ill., table 3), the organic-carbon and nitrogen transport are approximately equally distributed between the silt and clay and colloid fractions (table 5). For this particular cruise, the Upper Mississippi River contributed more organic carbon and nitrogen on the silt and clay and colloids to the Lower Mississippi River than did the Missouri, Ohio, and Arkansas Rivers. The water discharge of the Upper Mississippi River also was greater than the discharge of the Missouri, Ohio, and Arkansas Rivers during this sampling.

\section{SEPTEMBER-NOVEMBER 1991 CRUISE}

\section{Objectives and Approach}

The objectives were the same as in the first sampling cruise. The timing of this cruise enabled sampling of the Mississippi River during the low-water period and cooler temperature period of the fall. Presumably, the hydrologic and water temperature differences of the fall cruise as compared to the previous summer cruise would affect the quantity and quality of organic substances in the Mississippi River. In addition, the hydrophobic portion of the DOC was qualitatively assessed by isolating it from the ultrafiltered water samples on board the ACADIANA, and determining the 'H-NMR spectra of this DOC in the laboratory.

\section{Dissolved Organic Matter}

The hydrophobic portion of dissolved organic carbon was isolated by adsorption chromatography on XAD-8 resin. Ultrafiltered water was acidified $\mathrm{pH} 2$ with hydrolochloric acid, and then the acidified water was passed through a column packed with XAD-8 resin on board the ACADIANA. The column was eluted with methanol, and the $\mathrm{HCl}$ was neutralized with sodium bicarbonate to prevent the formation of methyl esters of DOC. In the laboratory, methanol was removed by vacuum evaporation, the DOC was reconcentrated on and eluted from an XAD-8 column to remove residual salts, and 'H-NMR spectra of this DOC were determined to characterize the DOC. DOC concentrations measured on samples collected during the upriver part of the sampling cruise are presented in table 6.

The downriver gains in water discharge in table 7 indicate nonadherence to Lagrangian sampling during the low water discharges of this cruise. Consequently, the data on dissolved organic carbon transport cannot be clearly interpreted with respect to instream gains or losses.

The downriver DOC concentrations in table 7 generally are greater than the upriver DOC concentrations in table 6. This difference illustrates changes during the elapsed time in sampling the river between the upriver and downriver parts of the cruise. 
Table 5. Organic-carbon and nitrogen transport on the silt and clay and colloid fractions for sediment samples collected during the downiver part of the June-August 1991 cruise

[Water discharge data used to compute transport are reported by Moody and Meade, 1994b]

\begin{tabular}{|c|c|c|c|c|c|c|}
\hline \multirow[b]{2}{*}{$\begin{array}{l}\text { Date } \\
1991\end{array}$} & \multirow[b]{2}{*}{ Site name } & \multirow[b]{2}{*}{$\begin{array}{c}\text { Water } \\
\text { dlscharge } \\
\text { (cubic meters } \\
\text { per second) }\end{array}$} & \multicolumn{2}{|c|}{ Transport on silt and clay } & \multicolumn{2}{|c|}{ Transport on collolds } \\
\hline & & & $\begin{array}{c}\text { Organic } \\
\text { carbon } \\
\text { (metric tons } \\
\text { per day) }\end{array}$ & $\begin{array}{c}\text { Nitrogen } \\
\text { (metric tons } \\
\text { per day) }\end{array}$ & $\begin{array}{c}\text { Organic } \\
\text { carbon } \\
\text { (metric tons } \\
\text { per day) }\end{array}$ & $\begin{array}{c}\text { Nitrogen } \\
\text { (metrlc tons } \\
\text { per day) }\end{array}$ \\
\hline 7.05 & $\begin{array}{l}\text { Mississippi River above } \\
\text { St. Anthony Falls, Minn. }\end{array}$ & 470 & 77 & 10 & 45 & 5 \\
\hline $7-06$ & Minnesota River at Mile 3.5, Minn. & 600 & 120 & 14 & 31 & 5 \\
\hline $7-08$ & Mississippi River at Hastings, Minn. & 980 & 200 & 28 & 76 & 10 \\
\hline $7-10$ & Mississippi River near Pepin, Wis. & 1,350 & 58 & 8 & 82 & 10 \\
\hline $7-12$ & $\begin{array}{l}\text { Mississippi River at } \\
\text { Trempealeau, Wis. }\end{array}$ & 1,440 & 140 & 20 & 87 & 10 \\
\hline $7-15$ & $\begin{array}{l}\text { Mississippi River below } \\
\text { Lock and Dam 9, Wis. }\end{array}$ & 1,590 & 360 & 49 & 110 & 14 \\
\hline $7-18$ & Mississippi River at Clinton, Iowa & 1,850 & 380 & 58 & 140 & 19 \\
\hline $7-21$ & Mississippi River at Keokuk, Iowa & 2,050 & 340 & 56 & 160 & 25 \\
\hline $7-24$ & Mississippi River near Winfield, Mo. & 2,730 & 640 & 100 & 170 & 23 \\
\hline $7-25$ & Illinois River at Hardin, Ill. & 260 & 29 & 4 & 18 & 2 \\
\hline $7-27$ & Missouri River at St. Charles, Mo. & 1,100 & 200 & 28 & 38 & 5 \\
\hline $7-29$ & Mississippi River at Thebes, Ill. & 4,390 & 760 & 120 & 230 & 33 \\
\hline $7-30$ & Ohio River at Olmsted, Ill. & 2,410 & 120 & 20 & 120 & 17 \\
\hline 8-03 & $\begin{array}{l}\text { Mississippi River below } \\
\text { Vicksburg, Miss. }\end{array}$ & 8,750 & 1,400 & 180 & 300 & 38 \\
\hline 8.05 & $\begin{array}{l}\text { Mississippi River near } \\
\text { St. Francisville, La. }\end{array}$ & 6,180 & 1,000 & 130 & 210 & 23 \\
\hline 8-07 & $\begin{array}{l}\text { Mississippi River below } \\
\text { Belle Chasse, La. }\end{array}$ & 4,340 & 300 & 30 & 75 & 8 \\
\hline
\end{tabular}


Table 6. Dissolved organic-carbon concentrations for samples during the upriver part of the September-November 1991 cruise listed in downriver order

[CDT, Central Daylight Time; mg/L, milligram per liter; --, no measurement]

\begin{tabular}{|c|c|c|}
\hline Time (CDT) & River mile ebove Head of Pesses, Louisiana' & $\begin{array}{l}\text { Dissoived orgenic-cerbon } \\
\text { concentration (mg/L) }\end{array}$ \\
\hline \multicolumn{3}{|c|}{ UPPER MISSISSIPPI RIVER } \\
\hline 2213 & $1,799.8$ & 10.5 \\
\hline 2155 & 1,797.8 Minnesota River & 7.7 \\
\hline 2023 & $1,791.8$ & 9.7 \\
\hline 1900 & $1,779.9$ & 9.7 \\
\hline 1729 & $1,766.3$ & 9.9 \\
\hline 1720 & 1,765.3 St. Croix River & 12.1 \\
\hline 1642 & $1,759.3$ & 10.6 \\
\hline 1520 & $1,746.9$ & 10.3 \\
\hline 1431 & $1,740.0$ & 10.5 \\
\hline 1319 & $1,730.2$ & 10.4 \\
\hline 1215 & $1,718.3$ & 10.0 \\
\hline 1108 & $1,709.3$ & 10.1 \\
\hline 0902 & $1,699.3$ & 9.7 \\
\hline 0545 & $1,689.5$ & 9.4 \\
\hline 0410 & $1,667.0$ & 9.3 \\
\hline 0316 & 1,652.0 Black River & 7.7 \\
\hline 0121 & $1,653.8$ & 9.0 \\
\hline \multicolumn{3}{|c|}{ October 3, 1991} \\
\hline 2313 & $1,639.9$ & 8.8 \\
\hline 2050 & $1,619.3$ & 8.6 \\
\hline 1932 & $1,606.8$ & 8.4 \\
\hline 1807 & $1,595.6$ & 8.4 \\
\hline 1703 & $1,586.8$ & 8.2 \\
\hline 1645 & 1,584.4 Wisconsin River & 7.7 \\
\hline 1548 & $1,575.1$ & 8.2 \\
\hline 1412 & $1,563.8$ & 8.2 \\
\hline 1246 & $1,556.0$ & 8.1 \\
\hline 1131 & $1,544.3$ & 8.2 \\
\hline 0904 & $1,535.3$ & 8.2 \\
\hline 0805 & $1,525.8$ & 8.1 \\
\hline 0656 & $1,514.5$ & 8.2 \\
\hline 0537 & $1,504.8$ & 8.0 \\
\hline 0248 & $1,484.8$ & 8.0 \\
\hline 0016 & $1,463.1$ & 7.8 \\
\hline
\end{tabular}


Table 6. Dissolved organic-carbon concentrations for samples during the upriver part of the September-November 1991 cruise listed in downriver order --Continued

\begin{tabular}{|c|c|c|}
\hline Time (CDT) & River mile above Hoed of Passes, Louisiana' & $\begin{array}{l}\text { Dissoived orgsnic-cerbon } \\
\text { concentration (mg/L) }\end{array}$ \\
\hline \multicolumn{3}{|c|}{$\begin{array}{l}\text { UPPER MISSISSIPPI RIVER-Continued } \\
\text { October } 2,1991\end{array}$} \\
\hline 2322 & $1,455.8$ & 7.9 \\
\hline 2141 & $1,444.8$ & 7.7 \\
\hline 2013 & $1,433.8$ & 7.8 \\
\hline 2005 & 1,432.8 Rock River & 6.7 \\
\hline 1837 & $1,418.8$ & 7.9 \\
\hline 1720 & $1,409.8$ & 8.0 \\
\hline 1626 & $1,400.8$ & 7.8 \\
\hline 1413 & $1,388.8$ & 7.8 \\
\hline 1321 & $1,380.8$ & 7.8 \\
\hline 1218 & $1,371.8$ & 7.2 \\
\hline 0928 & $1,360.8$ & 7.7 \\
\hline 0532 & $1,350.8$ & 7.6 \\
\hline 0347 & $1,335.8$ & 7.7 \\
\hline 0245 & $1,324.8$ & 7.7 \\
\hline 0136 & $1,316.8$ & 7.6 \\
\hline 0118 & 1,315.2 Des Moines River & 7.7 \\
\hline 0000 & $1,304.8$ & 7.7 \\
\hline \multicolumn{3}{|c|}{ October 1, 1991} \\
\hline 2212 & $1,294.8$ & 7.6 \\
\hline 2107 & $1,284.8$ & 7.6 \\
\hline 1852 & $1,274.8$ & 7.5 \\
\hline 1740 & $1,263.8$ & 7.7 \\
\hline 1553 & $1,253.3$ & 7.7 \\
\hline 1504 & $1,245.8$ & 7.7 \\
\hline 1407 & $1,237.1$ & 7.6 \\
\hline 1225 & $1,225.8$ & 7.5 \\
\hline 1109 & $1,214.0$ & 7.4 \\
\hline 1000 & $1,203.0$ & 7.4 \\
\hline 0700 & $1,194.0$ & 7.3 \\
\hline 0600 & $1,184.3$ & 7.4 \\
\hline 0507 & $1,175.4$ & 7.3 \\
\hline 0415 & 1,171.7 Illinois River & 4.8 \\
\hline 0253 & $1,161.0$ & 7.0 \\
\hline 0127 & $1,152.2$ & 6.9 \\
\hline
\end{tabular}


Table 6. Dissolved organic-carbon concentrations for samples during the upriver part of the September-November 1991 cruise listed in downriver order --Continued

\begin{tabular}{|c|c|c|}
\hline Time (CDT) & River mile above Head of Passes, Louisiana' & $\begin{array}{l}\text { Dissolved organic-carbon } \\
\text { concentration (mg/L) }\end{array}$ \\
\hline \multicolumn{3}{|c|}{ UPPER MISSISSIPPI RIVER-Continned } \\
\hline \multicolumn{3}{|c|}{ September 30, 1991} \\
\hline 2333 & 1,149.1 Missouri River & 3.1 \\
\hline 2139 & $1,134.1$ & 5.5 \\
\hline 1835 & $1,108.8$ & 5.7 \\
\hline 1521 & $1,082.7$ & 5.8 \\
\hline 1222 & $1,058.3$ & 5.5 \\
\hline 0924 & $1,034.6$ & 5.5 \\
\hline 0823 & $1,027.5$ & 5.5 \\
\hline 0712 & $1,017.4$ & 5.5 \\
\hline 0550 & $1,005.4$ & 5.5 \\
\hline 0413 & 992.8 & 5.5 \\
\hline 0315 & 984.6 & 5.5 \\
\hline 0148 & 973.6 & 5.5 \\
\hline 0039 & 964.6 & 5.6 \\
\hline \multicolumn{3}{|c|}{ September 29, 1991} \\
\hline 2121 & 953.8 Ohio River & 2.7 \\
\hline \multicolumn{3}{|c|}{ LOWER MISSISSIPPI RIVER } \\
\hline 2029 & 950.5 & 4.8 \\
\hline 1715 & 922.6 & 4.6 \\
\hline 1419 & 898.9 & 4.5 \\
\hline 1121 & 875.4 & 4.3 \\
\hline 1010 & 866.5 & 4.4 \\
\hline 0852 & 855.0 & 4.4 \\
\hline 0752 & 846.5 & 4.4 \\
\hline 0610 & 833.6 & 4.6 \\
\hline 0350 & 814.8 & 4.6 \\
\hline 0234 & 804.5 & 4.5 \\
\hline 0124 & 795.5 & 4.5 \\
\hline 2344 & 783.0 & 4.4 \\
\hline 2240 & 773.0 & 4.5 \\
\hline 2036 & 762.2 & 4.4 \\
\hline 1920 & 751.1 & 4.4 \\
\hline 1811 & 742.0 & 4.4 \\
\hline 1546 & 731.5 & 4.4 \\
\hline 1436 & 721.5 & 4.3 \\
\hline 1327 & 712.9 & 4.3 \\
\hline
\end{tabular}


Table 6. Dissolved organic-carbon concentrations for samples during the upriver part of the September-November 1991 cruise listed in downniver order --Continued

\begin{tabular}{|c|c|c|}
\hline Time (CDT) & River mile above Head of Passes, Louisisns' & $\begin{array}{l}\text { Dissoived organic-carbon } \\
\text { concentrstion (mg/L) }\end{array}$ \\
\hline \multicolumn{3}{|c|}{ LOWER MISSISSIPPI RIVER-Continned } \\
\hline \multicolumn{3}{|c|}{ September 29, 1991-Continned } \\
\hline 1200 & 702.0 & 4.3 \\
\hline 1031 & 689.9 & 4.3 \\
\hline 0858 & 679.4 & 4.3 \\
\hline 0752 & 669.9 & 4.3 \\
\hline 0640 & 660.2 & 4.3 \\
\hline 0527 & 650.2 & 4.3 \\
\hline 0427 & 641.7 & 4.4 \\
\hline 0252 & 629.3 & 4.3 \\
\hline 0122 & 617.7 & 4.2 \\
\hline 0047 & 608.8 & 4.2 \\
\hline \multicolumn{3}{|c|}{ September 27, 1991} \\
\hline 2309 & 601.0 & 4.2 \\
\hline 2111 & 590.3 & 4.1 \\
\hline 1957 & 580.8 & 4.2 \\
\hline 1750 & 562.8 & 4.1 \\
\hline 1630 & 551.8 & 4.0 \\
\hline 1544 & 545.0 & 4.0 \\
\hline 1335 & 534.5 & 4.1 \\
\hline 1225 & 524.9 & 4.0 \\
\hline 1059 & 514.1 & 3.9 \\
\hline 0953 & 504.5 & 3.9 \\
\hline 0825 & 493.0 & 3.8 \\
\hline 0730 & 485.2 & 3.8 \\
\hline 0615 & 474.5 & 3.8 \\
\hline 0433 & 460.8 & 3.8 \\
\hline 0312 & 449.2 & 3.7 \\
\hline 0208 & 439.8 & 3.8 \\
\hline 0114 & 432.0 & 3.7 \\
\hline \multicolumn{3}{|c|}{ September 26, 1991} \\
\hline 2345 & 420.1 & 3.8 \\
\hline 2235 & 409.5 & 3.8 \\
\hline 2111 & 398.8 & 3.8 \\
\hline 2007 & 389.6 & 3.8 \\
\hline 1900 & 380.5 & 3.8 \\
\hline
\end{tabular}


Table 6. Dissolved organic-carbon concentrations for samples during the upriver part of the September-November 1991 cruise listed in downriver order --Continued

\begin{tabular}{|c|c|c|}
\hline Time (CDT) & River mile above Head of Passes, Louisisna' & $\begin{array}{l}\text { Dissoived organic-csrbon } \\
\text { concentrstion (mg/L) }\end{array}$ \\
\hline \multicolumn{3}{|c|}{ LOWER MISSISSIPPI RIVER-Continued } \\
\hline \multicolumn{3}{|c|}{ September 26, 1991-Continued } \\
\hline 1704 & 371.2 & 3.7 \\
\hline 1555 & 360.0 & 3.7 \\
\hline 1447 & 351.3 & 3.7 \\
\hline 1334 & 340.0 & 3.6 \\
\hline 1229 & 330.4 & 3.6 \\
\hline 1128 & 321.1 & 3.5 \\
\hline 1019 & 310.0 & 3.6 \\
\hline \multicolumn{3}{|c|}{ September 26, 1991} \\
\hline 0924 & 301.0 & 3.5 \\
\hline 0758 & 289.6 & 3.5 \\
\hline 0655 & 279.7 & 3.4 \\
\hline 0545 & 269.9 & 3.8 \\
\hline 0435 & 258.8 & 3.4 \\
\hline 0337 & 249.0 & 3.6 \\
\hline 0241 & 240.0 & 4.3 \\
\hline \multicolumn{3}{|c|}{ September 25, 1991} \\
\hline 2120 & 230.0 & 3.7 \\
\hline 1950 & 216.2 & 3.7 \\
\hline 1850 & 206.8 & 3.7 \\
\hline 1742 & 195.1 & 3.6 \\
\hline 1635 & 184.8 & 3.6 \\
\hline 1532 & 175.4 & 3.6 \\
\hline 1430 & 164.7 & 3.7 \\
\hline 1325 & 155.6 & 3.6 \\
\hline 1235 & 145.0 & 3.7 \\
\hline 1126 & 134.9 & 3.6 \\
\hline 1019 & 123.1 & 3.7 \\
\hline 0922 & 113.9 & 3.8 \\
\hline 0853 & 105.1 & -- \\
\hline \multicolumn{3}{|c|}{ September 25, 1991} \\
\hline 0757 & 99.1 & 4.1 \\
\hline 0647 & 88.5 & 4.1 \\
\hline
\end{tabular}


Table 7. Dissolved organic carbon concentrations and transport for samples collected during the downriver part of the September-November 1991 cruise

[Dashes indicate sites that are not directly below a tributary; $\mathrm{mg} / \mathrm{L}$, milligram per liter; $\mathrm{m}^{3} / \mathrm{s}$, cubic meter per second]

\begin{tabular}{|c|c|c|c|c|c|c|c|}
\hline \multirow[b]{2}{*}{$\begin{array}{l}\text { Date } \\
1991\end{array}$} & \multirow[b]{2}{*}{ Site name } & \multirow{2}{*}{$\begin{array}{l}\text { River mile } \\
\text { above } \\
\text { Head } \\
\text { of Passes, } \\
\text { Louisiana' }\end{array}$} & \multirow{2}{*}{$\begin{array}{c}\text { Diseolved } \\
\text { organic } \\
\text { carbon } \\
\text { concentration } \\
\text { (mg/l) }\end{array}$} & \multirow[b]{2}{*}{$\begin{array}{c}\text { Water } \\
\text { dlscharge } \\
\left(\mathrm{m}^{3} / \mathrm{s}\right)\end{array}$} & \multirow{2}{*}{$\begin{array}{c}\text { Transport } \\
\text { of } \\
\text { dissolved } \\
\text { organic } \\
\text { carbon } \\
\text { (metric } \\
\text { tons per } \\
\text { day) }\end{array}$} & \multicolumn{2}{|c|}{$\begin{array}{l}\text { Cumulative percent gain } \\
\text { or loss below trlbutary }\end{array}$} \\
\hline & & & & & & $\begin{array}{c}\text { Water } \\
\text { discharge }\end{array}$ & $\begin{array}{l}\text { Carbon } \\
\text { transport }\end{array}$ \\
\hline $10-07$ & $\begin{array}{l}\text { Mississippi River above } \\
\text { St. Anthony Falls, Minn. }\end{array}$ & $1,811.5$ & 8.5 & 220 & 160 & -- & -- \\
\hline $10-08$ & $\begin{array}{l}\text { Minnesota River at } \\
\text { Mile 3.5, Minn. }\end{array}$ & $1,797.8$ & 7.4 & 130 & 83 & -- & -- \\
\hline $10-10$ & $\begin{array}{l}\text { Mississippi River at } \\
\text { Hastings, Minn. }\end{array}$ & $1,766.0$ & 9.2 & 350 & 280 & 0 & +15 \\
\hline $10-10$ & $\begin{array}{l}\text { St. Croix River at } \\
\text { Mile } 0.5 \text {, Wis. }\end{array}$ & $1,765.3$ & 15.3 & 95 & 130 & -- & -- \\
\hline $10-13$ & $\begin{array}{l}\text { Mississippi River near } \\
\text { Pepin, Wis. }\end{array}$ & $1,718.3$ & 11.3 & 510 & 500 & +15 & +34 \\
\hline $10-13$ & $\begin{array}{l}\text { Chippewa River at } \\
\text { Mile 1.7, Wis. }\end{array}$ & $1,717.2$ & 11.0 & 150 & 140 & -- & -- \\
\hline $10-15$ & $\begin{array}{l}\text { Mississippi River at } \\
\text { Trempealeau, Wis. }\end{array}$ & $1,667.6$ & 10.9 & 660 & 620 & +11 & +21 \\
\hline $10-18$ & $\begin{array}{l}\text { Mississippi River below } \\
\text { Lock and Dam 9, Wis. }\end{array}$ & $1,593.5$ & 8.3 & 690 & 500 & +16 & -3 \\
\hline $10-18$ & $\begin{array}{l}\text { Wisconsin River at } \\
\text { Mile 1.0, Wis. }\end{array}$ & $1,584.4$ & 5.1 & 160 & 71 & $\cdots$ & -- \\
\hline $10-22$ & $\begin{array}{l}\text { Mississippi River at } \\
\text { Clinton, lowa }\end{array}$ & $1,474.1$ & 8.7 & 940 & 710 & +25 & +22 \\
\hline $10-26$ & Rock River at Mile 1.0, Ill. & $1,432.8$ & 5.3 & 80 & 36 & -- & -- \\
\hline $10-26$ & Iowa River at Mile 1.0 , Iowa & $1,387.8$ & 4.0 & 70 & 24 & -- & - \\
\hline $10-27$ & $\begin{array}{l}\text { Mississippi River at } \\
\text { Keokuk, Iowa }\end{array}$ & $1,316.9$ & 6.0 & 1,410 & 730 & +56 & +14 \\
\hline $10-28$ & $\begin{array}{l}\text { Des Moines River at } \\
\text { Mile 1.0, Iowa }\end{array}$ & $1,315.2$ & 4.5 & 80 & 31 & -- & -- \\
\hline $10-30$ & $\begin{array}{l}\text { Mississippi River near } \\
\text { Winfield, Mo. }\end{array}$ & $1,193.0$ & 7.6 & 1,230 & 810 & +25 & +21 \\
\hline $10-31$ & $\begin{array}{l}\text { Illinois River at } \\
\text { Hardin, Ill. }\end{array}$ & $1,171.7$ & 4.2 & 520 & 190 & -- & -- \\
\hline $11-03$ & $\begin{array}{c}\text { Missouri River at } \\
\text { St. Charles, Mo. }\end{array}$ & $1,149.1$ & 3.9 & 1,350 & 450 & -- & -- \\
\hline $11-05$ & $\begin{array}{l}\text { Mississippi River at } \\
\text { Thebes, } 111 .\end{array}$ & 997.7 & 5.4 & 3,870 & 1,810 & +35 & +38 \\
\hline $11-06$ & Ohio River at Olmsted, Ill. & 953.8 & 3.0 & 2,480 & 640 & -- & -- \\
\hline
\end{tabular}


Table 7. Dissolved organic carbon concentrations and transport for samples collected during the downriver part of the September-November 1991 cruise --Continued

\begin{tabular}{|c|c|c|c|c|c|c|c|}
\hline \multirow[b]{2}{*}{$\begin{array}{l}\text { Date } \\
1991\end{array}$} & \multirow[b]{2}{*}{ Site name } & \multirow{2}{*}{$\begin{array}{c}\text { River mile } \\
\text { above } \\
\text { Head } \\
\text { of Passes, } \\
\text { Louisiana' }\end{array}$} & \multirow{2}{*}{$\begin{array}{c}\text { Dissolved } \\
\text { organic } \\
\text { carbon } \\
\text { concentration } \\
\text { (mg/L) }\end{array}$} & \multirow{2}{*}{$\begin{array}{c}\text { Water } \\
\text { discharge } \\
\left(\mathrm{m}^{3} / \mathrm{s}\right)\end{array}$} & \multirow{2}{*}{$\begin{array}{c}\text { Transport } \\
\text { of } \\
\text { dlssoived } \\
\text { organic } \\
\text { carbon } \\
\text { (metric } \\
\text { tons per } \\
\text { day) }\end{array}$} & \multicolumn{2}{|c|}{$\begin{array}{l}\text { Cumuiative percent gain } \\
\text { or loss below trlbutary }\end{array}$} \\
\hline & & & & & & $\begin{array}{c}\text { Water } \\
\text { discharge }\end{array}$ & $\begin{array}{l}\text { Carbon } \\
\text { transport }\end{array}$ \\
\hline $11-07$ & $\begin{array}{l}\text { White River at } \\
\text { Mile } 1.2, \text { Ark. }\end{array}$ & 598.0 & 3.8 & 1,210 & 400 & - & -- \\
\hline $11-07$ & $\begin{array}{l}\text { Arkansas River at } \\
\text { Mile 0.0, Ark. }\end{array}$ & $58 i .0$ & 4.6 & 1,620 & 640 & -- & -- \\
\hline $\mid \mathrm{I}-08$ & $\begin{array}{l}\text { Yazoo River at } \\
\text { Mile 3.0, Miss. }\end{array}$ & 437.0 & 3.6 & 540 & 170 & -- & -- \\
\hline $1 \mid-09$ & $\begin{array}{l}\text { Mississippi River beiow } \\
\text { Vicksburg, Miss. }\end{array}$ & 433.4 & 4.3 & 10,700 & 4,000 & +26 & +25 \\
\hline$|1-1|$ & $\begin{array}{l}\text { Mississippi River near } \\
\text { St. Francisville, La. }\end{array}$ & 266.4 & 3.7 & 8,950 & 2,900 & $+5^{3}$ & $-9^{3}$ \\
\hline $1 i-i 3$ & $\begin{array}{l}\text { Mississippi River below } \\
\text { Beile Chasse, La. }\end{array}$ & 73.1 & 4.8 & 8,840 & 3,700 & $+4^{3}$ & $+16^{3}$ \\
\hline
\end{tabular}

Tributary locations are Mississippi River miles at mouth of tributary.

${ }^{2}$ This value is the water discharge or carbon transport divided by the sum of all the inputs from tributaries upstream times 100 .

${ }^{3}$ Flow diversion to the Old River is responsible for the cumulative percentage change. 


\section{Organic Matter in Suspended-Sediment Fractions}

Concentrations of silt and clay and colloids were isolated, weighed, and analyzed in the same manner as on the previous downriver part of the June-August 1991 sampling cruise. These data and organic carbon concentrations are presented in table 8.

Recovery of the silt and clay, and colloid fractions ranged from 82 to 111 percent. The mean recovery was 92 percent. A similar pattern of recoveries as a function of the sampling site was observed during this cruise (September-November 1991) and the June-August 1991 cruise (tables 3 and 8).

Suspended-sediment concentrations were very low in the Upper Mississippi River during this period of low water discharge, but colloid and colloidal organic-carbon concentrations generally were similar to those for the previous sampling during the June-August 1991 cruise. Most of the sediment input during the September-November 1991 cruise was from the Missouri and Arkansas Rivers. Suspended-sediment concentrations were significantly greater in the Lower Mississippi River during the September-November 1991 cruise than during the June-August 1991 cruise, but colloidal organic-carbon concentrations were only slightly greater. The colloidal organic-carbon concentrations were generally lower in the Lower Mississippi River than in the Upper Mississippi River.

The organic-carbon and nitrogen composition of the silt and colloid fractions is listed in table 9. The results are given on a dry-weight percent basis.

The data in table 9 are notable for the exceptionally low $\mathrm{C}: \mathrm{N}$ ratios in the silt and clay fraction and the high organic-carbon percentages in the colloid fraction. The minimum silt and clay $\mathrm{C}: \mathrm{N}$ ratio is at the Keokuk, Iowa, site as it was for the summer sampling cruise (table 4). The low water discharge and low suspended-sediment conditions that existed in the Upper Mississippi River during September-November 1991 resulted in silt and clay with exceptionally high nitrogen content and colloids with exceptionally high organic-carbon content.

The transport calculations in table 10 show that relatively small quantities of organic carbon are transported in the Upper Mississippi River. Large increases in the organic-carbon and nitrogen loads at the Vicksburg, Miss., St. Francisville, La., and Belle Chasse, La., sites probably are caused by high water discharge and high suspendedsediment inputs from the White and Arkansas Rivers.

\section{MARCH-MAY 1992 CRUISE}

\section{Objectives}

The major objective of this sampling cruise was to repeat the studies of the previous two cruises under hydrologic and climatic conditions that exist in the spring. An early ice breakup on the navigation pools of the Upper Mississippi River made it possible to complete the upriver trip on schedule and begin the downriver trip at Minneapolis, Minnesota, by April 7, 1992.

\section{Dissolved Organic Matter}

Dissolved organic-carbon concentrations measured in water samples collected during the upriver part of the March-May 1992 cruise are presented in table 11. The DOC data in table 11 are the lowest DOC concentrations of the upriver sampling cruises. The early snow melt and runoff from tributaries in Wisconsin and Minnesota caused a water-discharge pulse in the Upper Mississippi River that was encountered just north of St. Louis (river mile 1200) during the upriver sampling cruise; however, this discharge pulse was not accompanied by a DOC pulse resulting from snowmelt, but rather a slight dilution of DOC was observed.

The DOC concentrations and transport determined from samples taken during the downriver leg are listed in table 12. Low water discharges occurred from Minneapolis downstream to Clinton, Iowa. However, the Iowa River and later the Missouri River were running "bank full", and inputs from these tributaries dramatically increased the water discharge and sediment concentrations for the remainder of the downstream sampling.

The DOC concentration data for the downriver part of the March-May 1992 cruise in table 12 were similar to the DOC concentration data for the upriver part in table 11 with a few exceptions. The high discharge of low DOC water from the Des Moines, Iowa, and Rock rivers diluted the DOC in the Mississippi River, whereas the 
Table 8. Concentrations of silt and clay and colloid fractions of suspended sediment and organic-carbon concentrations of these fractions for samples collected on the downriver part of the September-November 1991 cruise

[Suspended sediment concentrations are reported by Moody and Meade (1994b); <, less than; $\mu \mathrm{m}$, micrometer; $\mathrm{mg} / \mathrm{L}$, milligram per liter]

\begin{tabular}{|c|c|c|c|c|c|c|c|c|}
\hline \multirow{2}{*}{$\begin{array}{l}\text { Date } \\
1991\end{array}$} & \multirow[t]{2}{*}{ Site name } & \multirow{2}{*}{$\begin{array}{l}\text { River mile } \\
\text { above Head } \\
\text { of Passes, } \\
\text { Louisisns' }\end{array}$} & \multirow{2}{*}{$\begin{array}{l}\text { Suspended } \\
\text { sediment } \\
\text { concentrstion } \\
<63 \mu \mathrm{m} \\
(\mathrm{mg} / \mathrm{L})\end{array}$} & \multicolumn{2}{|c|}{$\begin{array}{l}\text { Concentrstions of } \\
\text { recovered } \\
\text { sediment frsctions }\end{array}$} & \multirow{2}{*}{$\begin{array}{l}\text { Recovery } \\
\text { of silt } \\
\text { and cisy } \\
\text { and } \\
\text { colioid } \\
\text { (percsnt) }\end{array}$} & \multicolumn{2}{|c|}{$\begin{array}{l}\text { Concentrations of } \\
\text { organic csrbon of } \\
\text { recovered } \\
\text { sediment fractions }\end{array}$} \\
\hline & & & & $\begin{array}{l}\text { Silt snd } \\
\text { clay } \\
(\mathrm{mg} / \mathrm{L})\end{array}$ & $\begin{array}{l}\text { Coiloid } \\
\text { (mg/L) }\end{array}$ & & $\begin{array}{l}\text { Silt snd } \\
\text { ciay } \\
(\mathrm{mg} / \mathrm{L})\end{array}$ & $\begin{array}{l}\text { Colloid } \\
(\mathrm{mg} / \mathrm{L})\end{array}$ \\
\hline $10-07$ & $\begin{array}{l}\text { Mississippi River above } \\
\text { St. Anthony Falls, Minn. }\end{array}$ & $1,811.5$ & 12 & $\overline{7.2}$ & 3.9 & 92 & 1.0 & 1.2 \\
\hline $10-08$ & $\begin{array}{l}\text { Minnesota River at } \\
\text { Mile 3.5, Minn. }\end{array}$ & $1,797.8$ & 62 & 52.3 & 5.7 & 94 & 3.0 & 0.9 \\
\hline $10-10$ & $\begin{array}{l}\text { Mississippi River at } \\
\text { Hastings, Minn. }\end{array}$ & $1,766.0$ & 45 & 41.3 & 4.6 & 102 & 2.7 & 1.0 \\
\hline $10-13$ & $\begin{array}{l}\text { Mississippi River near } \\
\text { Pepin, Wis. }\end{array}$ & $1,718.3$ & 9 & 5.0 & 2.4 & 82 & 0.5 & 0.7 \\
\hline $10-15$ & $\begin{array}{l}\text { Mississippi River at } \\
\text { Trempealeau, Wis. }\end{array}$ & $1,667.6$ & 12 & 7.9 & 2.6 & 88 & 0.9 & 0.7 \\
\hline $10-18$ & $\begin{array}{l}\text { Mississippi River below } \\
\text { Lock and Dam 9, Wis. }\end{array}$ & $1,593.5$ & 28 & 20.4 & 4.5 & 89 & 1.5 & 0.8 \\
\hline $10-22$ & $\begin{array}{l}\text { Mississippi River at } \\
\text { Clinton, Iowa }\end{array}$ & $1,474.1$ & 31 & 24.2 & 3.7 & 90 & 1.5 & 0.7 \\
\hline $10-27$ & $\begin{array}{l}\text { Mississippi River at } \\
\text { Keokuk, Iowa }\end{array}$ & $1,316.9$ & 32 & 25.7 & 3.9 & 92 & 1.6 & 0.8 \\
\hline $10-30$ & $\begin{array}{l}\text { Mississippi River near } \\
\text { Winfield, Mo. }\end{array}$ & $1,193.0$ & 36 & 30.4 & 5.0 & 98 & 1.7 & 0.8 \\
\hline $10-31$ & $\begin{array}{l}\text { Illinois River at } \\
\text { Hardin, Ill., Mile } 21.8\end{array}$ & $1,171.7$ & 143 & 147.3 & 11.2 & 111 & ${ }^{2} 2.7$ & 1.2 \\
\hline $11-03$ & $\begin{array}{l}\text { Missouri River at } \\
\text { St. Charles, Mo. }\end{array}$ & $1,149.1$ & 163 & 137.2 & 8.1 & 89 & 2.8 & 0.5 \\
\hline $11-05$ & $\begin{array}{l}\text { Mississippi River at } \\
\text { Thebes, Ill. }\end{array}$ & 997.7 & 80 & 66.3 & 6.7 & 91 & 1.9 & 0.7 \\
\hline $11-06$ & $\begin{array}{l}\text { Ohio River at } \\
\text { Olmsted, Ill. }\end{array}$ & 953.8 & 19 & 13.3 & 2.8 & 85 & 0.5 & 0.4 \\
\hline $11-09$ & $\begin{array}{l}\text { Mississippi River below } \\
\text { Vicksburg, Miss. }\end{array}$ & 433.4 & 154 & 128.8 & 10.5 & 90 & 1.9 & 0.6 \\
\hline $11-11$ & $\begin{array}{l}\text { Mississippi River near } \\
\text { St. Francisville, La. }\end{array}$ & 266.4 & 172 & 135.6 & 12.6 & 86 & 3.0 & 0.7 \\
\hline $11-13$ & $\begin{array}{l}\text { Mississippi River below } \\
\text { Belle Chasse, La. }\end{array}$ & 73.1 & 112 & 85.3 & 9.9 & 85 & 1.3 & 0.5 \\
\hline
\end{tabular}

${ }^{2}$ Average of duplicate analyses. 
Table 9. Organic-carbon and nitrogen contents of silt and clay and colloid fractions of suspended sediment for samples collected on the downiver part of the September-November 1991 cruise

[C, carbon; $N$, nitrogen]




Table 10. Organic-carbon and nitrogen transport on the silt and clay and colloid fractions for sediment samples collected on the downriver part of the September-November 1991 cruise

[Water discharge data used to compute transport are reported by Moody and Meade, 1994b]

\begin{tabular}{|c|c|c|c|c|c|c|}
\hline \multirow[b]{2}{*}{$\begin{array}{l}\text { Date } \\
1991\end{array}$} & \multirow[b]{2}{*}{ Site name } & \multirow[b]{2}{*}{$\begin{array}{c}\text { Water } \\
\text { discharge } \\
\text { (cubic meters } \\
\text { per second) }\end{array}$} & \multicolumn{2}{|c|}{ Transport on silt and clay } & \multicolumn{2}{|c|}{ Transport on collolds } \\
\hline & & & $\begin{array}{c}\text { Organlc } \\
\text { carbon } \\
\text { (metrlc tons } \\
\text { per day) }\end{array}$ & $\begin{array}{c}\text { Nitrogen } \\
\text { (metrlc tons } \\
\text { per day) }\end{array}$ & $\begin{array}{c}\text { Organic } \\
\text { carbon } \\
\text { (metric tons } \\
\text { per day) }\end{array}$ & $\begin{array}{c}\text { Nitrogen } \\
\text { (metrlc tona } \\
\text { per day) }\end{array}$ \\
\hline $10-07$ & $\begin{array}{l}\text { Mississippi River above } \\
\text { St. Anthony Falls, Minn. }\end{array}$ & 220 & 19 & 3 & 21 & 2 \\
\hline $10-08$ & Minnesota River at Mile 3.5, Minn. & 130 & 34 & 5 & 10 & 1 \\
\hline $10-10$ & Mississippi River at Hastings, Minn. & 350 & 82 & 13 & 82 & 3 \\
\hline $10-13$ & Mississippi River near Pepin, Wis. & 510 & 22 & 4 & 31 & 2 \\
\hline $10-15$ & $\begin{array}{l}\text { Mississippi River at } \\
\text { Trempealeau, Wis. }\end{array}$ & 660 & 51 & 8 & 40 & 4 \\
\hline $10-18$ & $\begin{array}{l}\text { Mississippi River below } \\
\text { Lock and Dam 9, Wis. }\end{array}$ & 690 & 130 & 23 & 72 & 9 \\
\hline $10-22$ & Mississippi River at Clinton, Iowa & 940 & 120 & 20 & 57 & 7 \\
\hline $10-27$ & Mississippi River at Keokuk, Iowa & 1,140 & 160 & 35 & 79 & 11 \\
\hline $10-30$ & Mississippi River near Winfield, Mo. & 1,230 & 180 & 30 & 85 & 11 \\
\hline $10-31$ & Illinois River at Hardin, Ill. & 520 & 120 & 16 & 54 & 7 \\
\hline $11-03$ & Missouri River at St. Charles, Mo. & 1,350 & 330 & 45 & 58 & 8 \\
\hline $11-05$ & Mississippi River at Thebes, IIl. & 3,870 & 640 & 100 & 270 & 32 \\
\hline $11-06$ & Ohio River at Olmsted, Ill. & 2,480 & 110 & 15 & 86 & 10 \\
\hline $11-09$ & $\begin{array}{l}\text { Mississippi River below } \\
\text { Vicksburg, Miss. }\end{array}$ & 10,700 & 1,800 & 250 & 550 & 75 \\
\hline $11-11$ & $\begin{array}{l}\text { Mississippi River near } \\
\text { St. Francisville, La. }\end{array}$ & 8,950 & 2,400 & 310 & 540 & 75 \\
\hline $11-13$ & $\begin{array}{l}\text { Mississippi River below } \\
\text { Belle Chasse, La. }\end{array}$ & 8,840 & 990 & 140 & 380 & 53 \\
\hline
\end{tabular}


Table 11. Dissolved organic carbon concentrations for samples collected during the upriver part of the March-May 1992 cruise listed in downriver order

[CDT, Central Daylight Time; mg/L, milligram per liter; --, no measurement]

\begin{tabular}{|c|c|c|}
\hline Time (CDT) & River mile above Head of Passes, Louisiana' & $\begin{array}{l}\text { Dissolved organic-carbon } \\
\text { concentrstion (mg/L) }\end{array}$ \\
\hline \multirow{2}{*}{\multicolumn{3}{|c|}{$\begin{array}{l}\text { UPPER MISSISSIPPI RIVER } \\
\text { April 4, } 1991\end{array}$}} \\
\hline & & \\
\hline 0733 & $1,799.4$ & 9.6 \\
\hline 0711 & 1,797.8 Minnesota River & 6.5 \\
\hline 0548 & $1,788.9$ & 8.3 \\
\hline 0304 & $1,779.9$ & 7.9 \\
\hline 0117 & $1,766.8$ & 8.0 \\
\hline 0103 & 1,765.3 St. Croix River & 9.6 \\
\hline 0015 & $1,759.3$ & 8.6 \\
\hline \multicolumn{3}{|c|}{ April 3, 1992} \\
\hline 2210 & $1,746.9$ & 8.3 \\
\hline 2107 & $1,730.2$ & 8.5 \\
\hline 2005 & $1,718.3$ & 8.6 \\
\hline 1953 & 1,717.2 Chippewa River & 8.3 \\
\hline 1859 & $1,709.3$ & 8.5 \\
\hline 1726 & $1,699.3$ & 8.1 \\
\hline 1614 & $1,689.5$ & 8.2 \\
\hline 1449 & $1,677.4$ & 8.0 \\
\hline 1307 & $1,663.3$ & 8.3 \\
\hline 1116 & $1,649.9$ & 8.2 \\
\hline 0955 & $1,638.1$ & 8.1 \\
\hline 0813 & $1,623.7$ & 8.0 \\
\hline 0628 & $1,606.8$ & 7.8 \\
\hline 0532 & $1,598.7$ & 7.4 \\
\hline 0406 & $1,585.7$ & 7.3 \\
\hline 0356 & 1,584.4 Wisconsin River & 7.5 \\
\hline 0245 & $1,574.8$ & 7.3 \\
\hline 0120 & $1,563.8$ & 7.3 \\
\hline \multicolumn{3}{|c|}{ April 2, 1992} \\
\hline 2237 & $1,550.8$ & 7.1 \\
\hline 2046 & $1,535.3$ & 7.3 \\
\hline 1951 & $1,526.7$ & 7.2 \\
\hline 1838 & $1,515.1$ & 7.2 \\
\hline 1716 & $1,502.8$ & 7.1 \\
\hline
\end{tabular}


Table 11. Dissolved organic carbon concentrations for samples collected during the upriver part of the March-May 1992 cruise listed in downriver order --Continued

\begin{tabular}{|c|c|c|}
\hline Time (CDT) & River mile above Head of Passes, Louisiana' & $\begin{array}{l}\text { Dissolved organic-carbon } \\
\text { concentration (mg/L) }\end{array}$ \\
\hline \multicolumn{3}{|c|}{ UPPER MISSISSIPPI RIVER-Continued } \\
\hline & April 2, 1991-Continued & \\
\hline 1530 & $1,486.8$ & 6.9 \\
\hline 1403 & $1,473.8$ & 6.9 \\
\hline 1228 & $1,460.2$ & 6.9 \\
\hline 1031 & $1,444.5$ & 6.9 \\
\hline 0908 & $1,435.4$ & 6.8 \\
\hline 0838 & 1,432.8 Rock River & 6.3 \\
\hline 0650 & $1,416.6$ & 6.7 \\
\hline 0539 & $1,406.8$ & 6.8 \\
\hline 0307 & 1,387.8 Iowa River & 6.6 \\
\hline 0156 & $1,378.8$ & 6.5 \\
\hline 0035 & $1,366.8$ & 6.5 \\
\hline \multicolumn{3}{|c|}{ April 1, 1992} \\
\hline 2121 & $1,356.8$ & 6.5 \\
\hline 1948 & $1,341.8$ & 6.7 \\
\hline 1823 & $1,327.8$ & 6.8 \\
\hline 1620 & $1,315.5$ & 6.1 \\
\hline 1615 & 1,315.2 Des Moines River & 3.9 \\
\hline 1437 & $1,300.8$ & 6.3 \\
\hline 1311 & $1,289.8$ & 5.4 \\
\hline 1143 & $1,278.4$ & 5.9 \\
\hline 0943 & $1,260.8$ & 5.7 \\
\hline 0745 & $1,246.8$ & 6.1 \\
\hline 0630 & $1,236.4$ & 6.0 \\
\hline 0454 & $1,223.8$ & 5.7 \\
\hline 0250 & $1,212.3$ & 5.6 \\
\hline 0123 & $1,199.8$ & 5.8 \\
\hline \multicolumn{3}{|c|}{ March 31, 1992} \\
\hline 2248 & $1,187.3$ & 5.7 \\
\hline 2125 & $1,174.8$ & 6.0 \\
\hline 2035 & 1,I71.7 Illinois River & 4.4 \\
\hline 1850 & $1,160.9$ & 5.9 \\
\hline 1717 & $1,152.1$ & 5.9 \\
\hline 1554 & 1,149.1 Missouri River & 4.9 \\
\hline 1405 & $1,134.1$ & 5.3 \\
\hline 1229 & $1,123.5$ & 5.3 \\
\hline 0903 & $1,099.5$ & 4.9 \\
\hline
\end{tabular}


Table 11. Dissolved organic carbon concentrations for samples collected during the upriver part of the March-May 1992 cruise listed in downriver order --Continued

\begin{tabular}{|c|c|c|}
\hline Time (CDT) & River mile above Head of Passes, Louisiana ${ }^{1}$ & $\begin{array}{l}\text { Dissoived organic-carbon } \\
\text { concentration }(\mathrm{mg} / \mathrm{L})\end{array}$ \\
\hline \multicolumn{3}{|c|}{ UPPER MISSIPPI RIVER-Continued } \\
\hline \multicolumn{3}{|c|}{ March 31, 1992-Continned } \\
\hline 0629 & $1,081.5$ & 5.1 \\
\hline 0450 & 1,071.1 Kaskaskia River & 7.3 \\
\hline 0340 & $1,063.6$ & 5.2 \\
\hline 0143 & $1,050.0$ & 5.1 \\
\hline \multicolumn{3}{|c|}{ March 30, 1991} \\
\hline 2346 & $1,034.3$ & 5.2 \\
\hline 2138 & $1,019.2$ & 5.1 \\
\hline 1920 & $1,003.2$ & 5.2 \\
\hline 1719 & 988.1 & 5.1 \\
\hline 1528 & 973.6 & 5.1 \\
\hline 1422 & 965.4 & 5.2 \\
\hline 1246 & 953.8 Ohio River & 2.8 \\
\hline \multicolumn{3}{|c|}{ LOWER MISSISSIPPI RIVER } \\
\hline 1047 & 950.5 & 4.4 \\
\hline 0713 & 923.0 & 3.8 \\
\hline 0400 & 898.9 & 4.0 \\
\hline 0107 & 878.1 & 4.0 \\
\hline \multicolumn{3}{|c|}{ March 29, 1991} \\
\hline 2105 & 848.0 & 3.9 \\
\hline 1926 & 837.4 & 3.8 \\
\hline 1810 & 828.0 & 3.9 \\
\hline 1644 & 815.8 & 3.8 \\
\hline 1513 & 804.7 & 3.8 \\
\hline 1356 & 795.5 & 3.9 \\
\hline 1227 & 784.6 & 3.8 \\
\hline 1103 & 774.0 & 4.0 \\
\hline 0940 & 763.0 & 4.0 \\
\hline 0820 & 752.9 & 3.9 \\
\hline 0640 & 742.0 & 3.8 \\
\hline 0544 & 735.0 & 3.8 \\
\hline 0143 & 723.3 & 3.9 \\
\hline 0029 & 714.3 & 4.1 \\
\hline \multicolumn{3}{|c|}{ March 28, 1992} \\
\hline 2308 & 705.0 & 3.9 \\
\hline 2138 & 695.0 & 3.9 \\
\hline 2011 & 683.4 & 3.8 \\
\hline 1843 & 672.7 & 3.8 \\
\hline
\end{tabular}


Table 11. Dissolved organic carbon concentrations for samples collected during the upriver part of the March-May 1992 cruise listed in downriver order --Continued

\begin{tabular}{|c|c|c|}
\hline Time (CDT) & River mile above Heed of Passes, Louisiana ${ }^{1}$ & $\begin{array}{l}\text { Dissolved organic-carbon } \\
\text { concentration (mg/L) }\end{array}$ \\
\hline \multicolumn{3}{|c|}{ LOWER MISSISSIPPI RIVER-Continued } \\
\hline \multicolumn{3}{|c|}{ March 28, 1992-Continned } \\
\hline 1659 & 659.8 & 3.8 \\
\hline 1540 & 650.1 & 3.6 \\
\hline 1401 & 638.7 & 3.8 \\
\hline 1229 & 626.6 & 3.6 \\
\hline 1040 & 614.1 & 3.7 \\
\hline 0858 & 602.0 & 3.8 \\
\hline 0734 & 592.1 & 3.6 \\
\hline 0613 & 582.0 & 3.7 \\
\hline 0550 & 581.0 Arkansas River & 4.2 \\
\hline 0317 & 565.1 & 3.7 \\
\hline 0139 & 555.0 & 3.6 \\
\hline 0009 & 544.9 & 3.5 \\
\hline \multicolumn{3}{|c|}{ March 27, 1992} \\
\hline 2128 & 535.0 & 3.6 \\
\hline 1951 & 525.0 & 3.6 \\
\hline 1823 & 514.1 & 3.6 \\
\hline 1651 & 504.5 & 3.6 \\
\hline \multicolumn{3}{|c|}{ March 27, 1992} \\
\hline 1532 & 495.1 & 3.6 \\
\hline 1410 & 485.5 & 3.6 \\
\hline 1246 & 475.0 & 3.6 \\
\hline 1121 & 464.8 & 3.7 \\
\hline 0957 & 454.3 & 3.6 \\
\hline 0847 & 445.2 & 3.7 \\
\hline 0729 & 435.3 & 3.7 \\
\hline 0531 & 421.8 & 3.6 \\
\hline 0402 & 409.5 & 3.6 \\
\hline 0234 & 399.4 & 3.7 \\
\hline 0117 & 389.8 & 3.6 \\
\hline 0019 & 380.0 & 3.5 \\
\hline \multicolumn{3}{|c|}{ March 26, 1992} \\
\hline 2252 & 371.2 & 3.1 \\
\hline 2011 & 360.0 & 3.5 \\
\hline 1853 & 351.3 & 3.5 \\
\hline 1731 & 340.0 & 3.4 \\
\hline 1620 & 330.4 & 3.5 \\
\hline
\end{tabular}


Table 11. Dissolved organic carbon concentrations for samples collected duning the upriver part of the March-May 1992 cruise listed in downriver order --Continued

\begin{tabular}{|c|c|c|}
\hline Time (CDT) & River mile above Head of Passes, Louisiana' & $\begin{array}{c}\text { Dissolved organic-carbon } \\
\text { concentration (mg/L) }\end{array}$ \\
\hline \multirow{2}{*}{\multicolumn{3}{|c|}{$\begin{array}{l}\text { LOWER MISSISSIPPI RIVER-Continued } \\
\text { March 26, 1992_Continued }\end{array}$}} \\
\hline & & \\
\hline 1515 & 321.1 & 3.5 \\
\hline 1354 & 310.0 & 3.5 \\
\hline 1243 & 300.0 & 3.4 \\
\hline 1131 & 290.0 & 3.5 \\
\hline 1018 & 280.0 & 3.6 \\
\hline 0907 & 270.0 & 3.5 \\
\hline 0804 & 260.8 & 3.5 \\
\hline 0647 & 250.0 & 3.4 \\
\hline 0532 & 240.3 & 3.5 \\
\hline \multicolumn{3}{|c|}{ March 25, 1992} \\
\hline 2348 & 228.0 & 3.4 \\
\hline 2236 & 220.0 & 3.4 \\
\hline 2124 & 210.0 & 3.3 \\
\hline 2011 & 200.0 & 3.4 \\
\hline 1900 & 190.0 & 3.3 \\
\hline 1752 & 179.5 & 3.3 \\
\hline 1649 & 170.0 & 3.2 \\
\hline 1539 & 160.1 & 3.3 \\
\hline 1424 & 149.7 & 3.2 \\
\hline 1312 & 139.8 & 3.2 \\
\hline 1205 & 130.0 & 3.3 \\
\hline 1044 & 119.0 & 3.3 \\
\hline 0938 & 110.0 & 3.3 \\
\hline 0829 & 100.0 & 3.2 \\
\hline 0705 & 90.0 & 3.3 \\
\hline
\end{tabular}

Mississippi River miles at mouths of tributaries. 
Table 12. Dissolved organic-carbon concentrations and transport for samples collected during the downriver part of the MarchMay 1992 cruise

[Dashes indicate sites that are not directly below a tributary; $\mathrm{mg} / \mathrm{L}$, milligram per liter; and $\mathrm{m}^{3} / \mathrm{s}$, cubic meter per second]

\begin{tabular}{|c|c|c|c|c|c|c|c|}
\hline \multirow[b]{2}{*}{$\begin{array}{l}\text { Date } \\
1991\end{array}$} & \multirow[b]{2}{*}{ Site name } & \multirow{2}{*}{$\begin{array}{c}\text { River mile } \\
\text { above } \\
\text { Head } \\
\text { of Passes, } \\
\text { Louisiana' }\end{array}$} & \multirow{2}{*}{$\begin{array}{c}\text { Dissolved } \\
\text { organic } \\
\text { carbon } \\
\text { concentration } \\
\text { (mg/L) }\end{array}$} & \multirow[b]{2}{*}{$\begin{array}{c}\text { Water } \\
\text { discharge } \\
\left(\mathrm{m}^{3} / \mathrm{s}\right)\end{array}$} & \multirow{2}{*}{$\begin{array}{l}\text { Transport } \\
\text { of } \\
\text { dissolved } \\
\text { organic } \\
\text { carbon } \\
\text { (metric } \\
\text { tons per } \\
\text { day) }\end{array}$} & \multicolumn{2}{|c|}{$\begin{array}{l}\text { Cumulative percent gain } \\
\text { or loaa below tributary }\end{array}$} \\
\hline & & & & & & $\begin{array}{c}\text { Watar } \\
\text { discharga }\end{array}$ & $\begin{array}{l}\text { Carbon } \\
\text { traneport }\end{array}$ \\
\hline $4-06$ & $\begin{array}{l}\text { Mississippi River above } \\
\text { St. Anthony Falls, Minn. }\end{array}$ & $1,811.5$ & 10.6 & 310 & 284 & - & -- \\
\hline $4-08$ & $\begin{array}{l}\text { Minnesota River at } \\
\text { Mile 3.5, Minn. }\end{array}$ & $1,797.8$ & 6.2 & 260 & 140 & -- & -- \\
\hline 4-10 & $\begin{array}{l}\text { Mississippi River at } \\
\text { Hastings, Minn. }\end{array}$ & $1,766.0$ & 7.6 & 570 & 374 & 0 & -12 \\
\hline $4-11$ & $\begin{array}{l}\text { St. Croix River at } \\
\text { Mile } 0.5 \text {, Wis. }\end{array}$ & $1,765.3$ & 6.7 & 320 & 185 & -- & -- \\
\hline $4-12$ & $\begin{array}{l}\text { Mississippi River near } \\
\text { Pepin, Wis. }\end{array}$ & $1,718.3$ & 7.5 & 950 & 615 & +7 & +1 \\
\hline $4-12$ & $\begin{array}{l}\text { Chippewa River at } \\
\text { Mile 1.7, Wis. }\end{array}$ & $1,717.2$ & 6.9 & 300 & 179 & -- & -- \\
\hline $4-14$ & $\begin{array}{l}\text { Mississippi River at } \\
\text { Trempealeau, Wis. }\end{array}$ & $1,667.6$ & 6.8 & 1,330 & 781 & +12 & -1 \\
\hline $4-17$ & $\begin{array}{l}\text { Mississippi River below } \\
\text { Lock and Dam 9, Wis. }\end{array}$ & $1,593.5$ & 6.3 & 1,590 & 865 & +34 & +10 \\
\hline $4-17$ & $\begin{array}{l}\text { Wisconsin River at } \\
\text { Mile } 1.0, \text { Wis. }\end{array}$ & $1,584.4$ & 5.6 & 889 & 655 & -- & -- \\
\hline $4-19$ & $\begin{array}{l}\text { Mississippi River at } \\
\text { Clinton, Iowa }\end{array}$ & $1,474.1$ & 6.4 & 2,320 & 1,283 & +12 & -11 \\
\hline $4-22$ & Rock River at Mile 1.0, Ill. & $1,432.8$ & 2.3 & 340 & 68 & -- & -- \\
\hline $4-22$ & Iowa River at Mile 1.0, Iowa & $1,387.8$ & 3.1 & 680 & 182 & - & -- \\
\hline $4-23$ & $\begin{array}{l}\text { Mississippi River at } \\
\text { Keokuk, Iowa }\end{array}$ & $1,316.9$ & 4.9 & 4,220 & 1,786 & +36 & 5 \\
\hline $4-24$ & $\begin{array}{l}\text { Des Moines River at } \\
\text { Mile 1.0, Iowa }\end{array}$ & $1,315.2$ & 3.8 & 730 & 240 & -- & -- \\
\hline $4-26$ & $\begin{array}{l}\text { Mississippi River near } \\
\text { Winfield, Mo. }\end{array}$ & $1,193.0$ & 4.8 & 5,070 & 2,103 & +32 & +9 \\
\hline $4-27$ & $\begin{array}{l}\text { Illinois River at } \\
\text { Hardin, Ill. }\end{array}$ & $1,171.7$ & 3.5 & 860 & 260 & - & - \\
\hline $4-29$ & $\begin{array}{l}\text { Missouri River at } \\
\text { St. Charles, Mo. }\end{array}$ & $1,149.1$ & 9.0 & 3,560 & 2,768 & -- & -- \\
\hline $4-30$ & $\begin{array}{l}\text { Kaskaskia River at } \\
\text { Mile 1.5, Ill. }\end{array}$ & $1,071.1$ & 5.9 & 30 & 15 & - & -- \\
\hline
\end{tabular}


Table 12. Dissolved organic-carbon concentrations and transport for samples collected during the downriver part of the MarchMay 1992 cruise --Continued

\begin{tabular}{|c|c|c|c|c|c|c|c|}
\hline \multirow[b]{2}{*}{$\begin{array}{l}\text { Date } \\
1991\end{array}$} & \multirow[b]{2}{*}{ Site name } & \multirow{2}{*}{$\begin{array}{c}\text { River mile } \\
\text { above } \\
\text { Head } \\
\text { of Passes, } \\
\text { Louisiana' }\end{array}$} & \multirow{2}{*}{$\begin{array}{c}\text { Dissoived } \\
\text { organic } \\
\text { carbon } \\
\text { concentration } \\
\text { (mg/L) }\end{array}$} & \multirow{2}{*}{$\begin{array}{c}\text { Water } \\
\text { discharge } \\
\left(\mathrm{m}^{3} / \mathrm{s}\right)\end{array}$} & \multirow{2}{*}{$\begin{array}{c}\text { Transport } \\
\text { of } \\
\text { dissoived } \\
\text { organic } \\
\text { carbon } \\
\text { (metric } \\
\text { tons per } \\
\text { day) }\end{array}$} & \multicolumn{2}{|c|}{$\begin{array}{l}\text { Cumulative percent gain } \\
\text { or loss beiow tributary }\end{array}$} \\
\hline & & & & & & $\begin{array}{c}\text { Water } \\
\text { dlscharge }\end{array}$ & $\begin{array}{l}\text { Carbon } \\
\text { tranaport }\end{array}$ \\
\hline $5-01$ & $\begin{array}{l}\text { Mississippi River at } \\
\text { Thebes, ill. }\end{array}$ & 997.7 & 5.1 & 10,500 & 4,620 & +27 & -7 \\
\hline $5-03$ & $\begin{array}{l}\text { Ohio River at } \\
\text { Oimsted, } 111 .\end{array}$ & 953.8 & 2.0 & 6,150 & 1,060 & -- & -- \\
\hline 5-04 & $\begin{array}{l}\text { White River at } \\
\text { Miie 1.2, Ark. }\end{array}$ & 598.0 & 2.2 & 920 & 175 & -- & -- \\
\hline 5-04 & $\begin{array}{l}\text { Arkansas River at } \\
\text { Miie } 0.0, \text { Ark. }\end{array}$ & 581.0 & 6.2 & 710 & 380 & -- & -- \\
\hline $5-05$ & $\begin{array}{l}\text { Yazoo River at } \\
\text { Mile 3.0, Miss. }\end{array}$ & 437.0 & 3.2 & 70 & 19 & -- & -- \\
\hline $5-06$ & $\begin{array}{l}\text { Mississippi River beiow } \\
\text { Vicksburg, Miss. }\end{array}$ & 433.4 & 3.0 & 21,800 & 5,640 & +35 & -15 \\
\hline $5-08$ & $\begin{array}{l}\text { Mississippi River near } \\
\text { St. Francisville, La. }\end{array}$ & 266.4 & 2.7 & 15,100 & 3,520 & $-6^{3}$ & $-47^{3}$ \\
\hline $5-10$ & $\begin{array}{l}\text { Mississippi River beiow } \\
\text { Beile Chasse, La. }\end{array}$ & 73.1 & 3.0 & 14,500 & 3,760 & $-10^{3}$ & $-43^{3}$ \\
\hline
\end{tabular}

Tributary locations are Mississippi River miles at mouth of tributary.

${ }^{2}$ This value is the water discharge or carbon transport divided by the sum of all the inputs from tributaries upstream times 100 .

${ }^{3}$ Flow diversion to the Old River is responsible for the cumulative percentage change. 
high discharge in the Missouri River was accompanied by a high DOC that enriched the DOC in the Mississippi River.

The difference in cumulative percentages below tributary confluences between water discharge percentage in minus DOC transport percentage are consistently negative. This negative mass balance is a possible indication of instream degradation of DOC, although the positive bias in the mass balance data of water discharge indicates that same parcel of water was not being consistently sampled downstream, and variations in DOC concentrations between different parcels of water can also explain this data set.

\section{Organic Matter in Suspended-Sediment Fractions}

Silt and clay and colloids were isolated, weighed, and analyzed in the same manner as on the previous downriver cruises. The data are presented in table 13.

The high water discharge and suspended-sediment concentrations in the Iowa and Missouri Rivers caused large increases in the suspended-silt and clay concentrations in the Mississippi River (table 13). Only slight increases in colloidal organic-carbon concentrations were observed with large increases in suspended-silt and clay concentrations. The constancy of the colloidal organic-carbon concentrations is remarkable, considering the large variations in suspended-sediment concentrations during this sampling cruise.

The organic-carbon and nitrogen composition of the silt and colloid fractions is listed in table 14. The results are given on a dry-weight percent basis.

The most notable feature of the compositional data in table 14 is the abrupt decrease in organic carbon and nitrogen percentages of the silt and clay and colloid fractions in the Mississippi River as high concentrations of suspended sediment from the Iowa River and the Missouri River enter the Mississippi River. The atomic C: $\mathrm{N}$ ratio generally appears to vary inversely among sampling locations between the silt and clay, and colloid fractions. The atomic $\mathrm{C}: \mathrm{N}$ ratio of the colloid fraction at Keokuk, Iowa, is especially low (7.9).

The data in tables 13 and 14 and were used to calculate transport of organic carbon and nitrogen in the silt and clay and colloidal phases. These results are shown in table 15.

The organic carbon and nitrogen transport for the silt and clay fraction in the Mississippi River show large increases at the Keokuk and Thebes, Ill., sites because of large sediment inputs from the Iowa and Missouri Rivers. The transport downriver from these tributaries are the largest measured for any of the three sampling cruises. The magnitude of the increase in organic carbon and nitrogen loads of the colloids at the Keokuk and Thebes sites is much less than the increases for the silt fractions at these sites.

\section{ORGANIC MATTER IN BED SEDIMENTS}

Bed sediments were sampled and composited for the lower portion of the navigation pools. The specific locations, method of sampling, and method of compositing are given in the report to be published as an Open-File Report by the U.S. Geological Survey titled "Hydrologic, sedimentologic and chemical data describing water and bed sediments in the navigation pools of the Upper Mississippi River, July 1991-April 1992. In addition, bed-sediment samples were taken in the Lower Mississippi River and certain tributaries at sites where fine sediments accumulated (behind wing dams and bridge abutments). The organic-carbon and nitrogen contents of these bed-sediment samples are listed in table 16.

The contents of organic carbon and nitrogen in the bed sediments are much lower than in the suspended silt and clay and colloid fractions because of the presence of inorganic sands in the bed sediments. The bed-sediment samples with the greatest organic-carbon content are from Lower Lake Pepin (Pool 4), which is the most efficient sediment trap for fine-grained and high organic-carbon sediments on the Upper Mississippi River.

The atomic $\mathrm{C}: \mathrm{N}$ ratio is one indicator of the trophic status of the bed sediments; low $\mathrm{C}: \mathrm{N}$ ratios indicate incomplete biological decomposition of organic nitrogen and ammonia in eutrophic bed sediments. Lake Pepin, Pool 19, Pool 22, Pool 24, and the site near Thebes, Ill., all have low C:N ratios that may indicate excess nitrogen in bed sediments. This excess nitrogen may result in ammonia production in sediment pore waters during periods of low oxygen and high biological activity. The Pig's Eye Slough sample has a low $\mathrm{C}: \mathrm{N}$ ratio because this sample was taken just below the outfall of the Minneapolis-St. Paul sewage-treatment plant.

A comparison of the organic-carbon and nitrogen contents of bed-sediment samples with suspended silt and clay samples that were collected in close proximity to each other is given in table 17 . 
Table 13. Concentrations of silt and clay and colloid fractions of suspended sediment and organic-carbon concentrations of these fractions for samples collected on the downriver part of the March-May 1992 cruise

[Suspended sediment concentrations are reported by Moody and Meade (1994b); <, less than; $\mu \mathrm{m}$, micrometer; mg/L, milligram per liter]

\begin{tabular}{|c|c|c|c|c|c|c|c|c|}
\hline \multirow{2}{*}{$\begin{array}{l}\text { Dste } \\
1991\end{array}$} & \multirow[t]{2}{*}{ Slte nsme } & \multirow{2}{*}{$\begin{array}{l}\text { River mile } \\
\text { sbove Head } \\
\text { of Passes, } \\
\text { Louisiana' }\end{array}$} & \multirow{2}{*}{$\begin{array}{l}\text { Suspended } \\
\text { sediment } \\
\text { concentration } \\
<63 \mu \mathrm{m} \\
\text { (mg/L) }\end{array}$} & \multicolumn{2}{|c|}{$\begin{array}{l}\text { Concentrations of } \\
\text { recovered } \\
\text { sediment fractions }\end{array}$} & \multirow{2}{*}{$\begin{array}{l}\text { Recovery } \\
\text { of siit } \\
\text { snd cisy } \\
\text { and } \\
\text { collold } \\
\text { (percent) }\end{array}$} & \multicolumn{2}{|c|}{$\begin{array}{l}\text { Concentrations of } \\
\text { organic carbon of } \\
\text { recovered } \\
\text { sediment fractions }\end{array}$} \\
\hline & & & & $\begin{array}{l}\text { Siit snd } \\
\text { clay } \\
(\mathrm{mg} / \mathrm{L})\end{array}$ & $\begin{array}{l}\text { Colloid } \\
\text { (mg/L) }\end{array}$ & & $\begin{array}{c}\text { Siit and } \\
\text { cisy } \\
\text { (mg/t) }\end{array}$ & $\begin{array}{l}\text { Collold } \\
(\mathrm{mg} / \mathrm{L})\end{array}$ \\
\hline $4-06$ & $\begin{array}{l}\text { Mississippi River above } \\
\text { St. Anthony Falls, Minn. }\end{array}$ & $1,811.5$ & 12 & 7.7 & 0.9 & 72 & 1.3 & 0.1 \\
\hline 4-08 & $\begin{array}{l}\text { Minnesota River at } \\
\text { Mile 3.5, Minn. }\end{array}$ & $1,797.8$ & 96 & 89.6 & 5.8 & 99 & 2.5 & 0.8 \\
\hline $4-10$ & $\begin{array}{l}\text { Mississippi River at } \\
\text { Hastings, Minn. }\end{array}$ & $1,766.0$ & 36 & 29.7 & 4.6 & 95 & 1.9 & 0.9 \\
\hline $4-12$ & $\begin{array}{l}\text { Mississippi River near } \\
\text { Pepin, Wis. }\end{array}$ & $1,718.3$ & 12 & 8.1 & 3.2 & 94 & 0.9 & 0.9 \\
\hline 4-14 & $\begin{array}{l}\text { Mississippi River at } \\
\text { Trempealeau, Wis. }\end{array}$ & $1,667.6$ & 14 & 10.1 & 3.4 & 96 & 1.0 & 0.9 \\
\hline 4-17 & $\begin{array}{l}\text { Mississippi River below } \\
\text { Lock and Dam 9, Wis. }\end{array}$ & $1,593.5$ & 24 & 19.4 & 3.2 & 94 & 1.4 & 0.8 \\
\hline 4-19 & $\begin{array}{l}\text { Mississippi River at } \\
\text { Clinton, Iowa }\end{array}$ & $1,474.1$ & 40 & 31.0 & 3.9 & 87 & 1.9 & 0.9 \\
\hline 4.23 & $\begin{array}{l}\text { Mississippi River at } \\
\text { Keokuk, Iowa }\end{array}$ & $1,316.9$ & 299 & 132 & 15.6 & 49 & 3.5 & 1.1 \\
\hline $4-26$ & $\begin{array}{l}\text { Mississippi River near } \\
\text { Winfield, Mo. }\end{array}$ & $1,193.0$ & 293 & 200 & 13.7 & 73 & 4.8 & ${ }^{2} 1.1$ \\
\hline 4-27 & Illinois River at Hardin, Ill. & $1,171.7$ & 230 & 256 & 9.4 & 115 & 5.2 & 0.8 \\
\hline $4-29$ & $\begin{array}{l}\text { Missouri River at } \\
\text { St. Charles, Mo. }\end{array}$ & $1,149.1$ & 1,180 & 1,146 & 36.6 & 100 & 14.4 & 1.5 \\
\hline 5-01 & $\begin{array}{l}\text { Mississippi River at } \\
\text { Thebes, Ill. }\end{array}$ & 997.7 & 600 & 577 & 20.7 & 100 & 8.5 & 1.1 \\
\hline $5-03$ & Ohio River at Olmsted, Ill. & 953.8 & 67 & 58.4 & 4.6 & 94 & 1.4 & 0.5 \\
\hline $5-06$ & $\begin{array}{l}\text { Mississippi River below } \\
\text { Vicksburg, Miss. }\end{array}$ & 433.4 & 300 & 275 & 17.8 & 98 & 4.9 & 0.9 \\
\hline $5-08$ & $\begin{array}{l}\text { Mississippi River near } \\
\text { St. Francisville, La. }\end{array}$ & 266.4 & 297 & 240 & 17.0 & 87 & 4.3 & 0.8 \\
\hline $5-10$ & $\begin{array}{l}\text { Mississippi River below } \\
\text { Belle Chasse, La. }\end{array}$ & 73.1 & 303 & 248 & 17.1 & 87 & 4.4 & 0.8 \\
\hline
\end{tabular}

${ }^{2}$ Average of duplicate analyses. 
Table 14. Organic-carbon and nitrogen contents of silt and clay and colloid fractions of suspended sediment for samples collected on the downniver part of the March-May 1992 cruise

[C, carbon; $\mathbf{N}$, nitrogen]

\begin{tabular}{|c|c|c|c|c|c|c|c|}
\hline \multirow[b]{2}{*}{$\begin{array}{l}\text { Date } \\
1991\end{array}$} & \multirow[b]{2}{*}{ Site name } & \multicolumn{3}{|c|}{ Slit and clay fractlon } & \multicolumn{3}{|c|}{ Colloid fraction } \\
\hline & & $\begin{array}{l}\text { Organic } \\
\text { carbon } \\
\text { (percent) }\end{array}$ & $\begin{array}{l}\text { Nitrogen } \\
\text { (percent) }\end{array}$ & $\begin{array}{l}\text { Atomic } \\
\text { C:N ratio }\end{array}$ & $\begin{array}{l}\text { Organlc } \\
\text { carbon } \\
\text { (percent) }\end{array}$ & $\begin{array}{l}\text { Nitrogen } \\
\text { (percent) }\end{array}$ & $\begin{array}{l}\text { Atomic } \\
\text { C:N ratio } \\
\text { (percent) }\end{array}$ \\
\hline $4-06$ & $\begin{array}{l}\text { Mississippi River above } \\
\text { St. Anthony Falls, Minn. }\end{array}$ & 17 & 2.9 & 6.8 & 11 & 1.6 & 10.2 \\
\hline 4-08 & Minnesota River at Mile 3.5, Minn. & 2.8 & 0.5 & 7.0 & 14 & 1.9 & 8.8 \\
\hline $4-10$ & Mississippi River at Hastings, Minn. & 6.4 & 1.1 & 6.6 & 20 & 2.4 & 9.5 \\
\hline 4-12 & Mississippi River near Pepin, Wis. & 11 & 1.9 & 6.9 & 28 & 3.3 & 9.6 \\
\hline $4-14$ & Mississippi River at Trempealeau, Wis. & 9.9 & 1.6 & 7.3 & 26 & 2.7 & 11.2 \\
\hline $4-17$ & $\begin{array}{l}\text { Mississippi River below } \\
\text { Lock and Dam 9, Wis. }\end{array}$ & 7.2 & 1.3 & 6.8 & 25 & 2.7 & 11.2 \\
\hline $4-19$ & Mississippi River at Clinton, Iowa & 6.1 & 1.0 & 7.0 & 23 & 2.5 & 10.9 \\
\hline 4-23 & Mississippi River at Keokuk, Iowa & 2.7 & 0.3 & 10.5 & 7.1 & 1.1 & 7.9 \\
\hline $4-26$ & Mississippi River near Winfield, Mo. & 2.4 & 0.3 & 10.0 & 8.0 & 1.0 & 9.3 \\
\hline $4-27$ & Illinois River at Hardin, Ill. & 2.0 & 0.2 & 10.7 & 9.6 & 1.3 & 8.1 \\
\hline 4-29 & Missouri River at St. Charles, Mo. & 1.3 & 0.1 & 13.4 & 4.1 & 0.5 & 10.2 \\
\hline $5-01$ & Mississippi River at Thebes, Ill. & 1.5 & 0.2 & 10.3 & 5.3 & 0.7 & 8.1 \\
\hline $5-03$ & Ohio River at Olmsted, Ill. & 2.4 & 0.3 & 10.0 & 11 & 1.3 & 8.2 \\
\hline $5-06$ & Mississippi River below Vicksburg, Miss. & 1.8 & 0.2 & 10.3 & 5.1 & 0.6 & 9.4 \\
\hline $5-08$ & Mississippi River near St. Francisville, La. & 1.8 & 0.2 & 10.4 & 4.7 & 0.6 & 9.6 \\
\hline $5-10$ & Mississippi River below Belle Chasse, La. & 1.8 & 0.2 & 10.8 & 4.7 & 0.6 & 9.7 \\
\hline
\end{tabular}


Table 15. Organic-carbon and nitrogen transport on the silt and clay and colloid fractions for sediment samples collected on the downniver part of the March-May 1992 cruise

[Water discharge data used to compute transport are reported by Moody and Meade, 1994b]

\begin{tabular}{|c|c|c|c|c|c|c|}
\hline \multirow[b]{2}{*}{$\begin{array}{l}\text { Date } \\
1991\end{array}$} & \multirow[b]{2}{*}{ Site name } & \multirow[b]{2}{*}{$\begin{array}{c}\text { Water } \\
\text { discharge } \\
\text { (cubic meters } \\
\text { per second) }\end{array}$} & \multicolumn{2}{|c|}{ Transport on silt and clay } & \multicolumn{2}{|c|}{ Transport on collolds } \\
\hline & & & $\begin{array}{c}\text { Organlc } \\
\text { carbon } \\
\text { (metric tons } \\
\text { per day) }\end{array}$ & $\begin{array}{c}\text { Nitrogen } \\
\text { (metric tons } \\
\text { per day) }\end{array}$ & $\begin{array}{c}\text { Organic } \\
\text { carbon } \\
\text { (metric tons } \\
\text { per day) }\end{array}$ & $\begin{array}{c}\text { Nitrogen } \\
\text { (metric tons } \\
\text { per day) }\end{array}$ \\
\hline $4-06$ & $\begin{array}{l}\text { Mississippi River above } \\
\text { St. Anthony Falis, Minn. }\end{array}$ & 310 & 35 & 6 & 3 & 0.4 \\
\hline 4-08 & Minnesota River at Mile 3.5, Minn. & 260 & 56 & 9 & 18 & 2 \\
\hline $4-10$ & Mississippi River at Hastings, Minn. & 570 & 94 & 17 & 44 & 6 \\
\hline $4-12$ & Mississippi River near Pepin, Wis. & 950 & 74 & 13 & 74 & 9 \\
\hline 4-14 & $\begin{array}{l}\text { Mississippi River at } \\
\text { Trempealeau, Wis. }\end{array}$ & 1,330 & 110 & 18 & 100 & 11 \\
\hline $4-17$ & $\begin{array}{l}\text { Mississippi River below } \\
\text { Lock and Dam 9, Wis. }\end{array}$ & 1,590 & 190 & 34 & 110 & 12 \\
\hline 4-19 & Mississippi River at Clinton, Jowa & 2,320 & 381 & 64 & 180 & 18 \\
\hline $4-23$ & Mississippi River at Keokuk, Iowa & 4,220 & 1,300 & 140 & 400 & 61 \\
\hline $4-26$ & Mississippi River near Winfield, Mo. & 5,070 & 2,100 & 250 & 480 & 60 \\
\hline $4-27$ & 11linois River at Hardin, Ill. & 860 & 390 & 42 & 67 & 9 \\
\hline 4-29 & Missouri River at St. Charles, Mo. & 3,560 & 4,430 & 390 & 460 & 53 \\
\hline 5-01 & Mississippi River at Thebes, Ill. & 10,500 & 7,710 & 870 & 1,000 & 120 \\
\hline $5-03$ & Ohio River at Olmsted, Ill. & 6,150 & 740 & 84 & 270 & 32 \\
\hline $5-06$ & $\begin{array}{l}\text { Mississippi River below } \\
\text { Vicksburg, Miss. }\end{array}$ & 21,800 & 9,200 & 1,030 & 1,700 & 200 \\
\hline $5-08$ & $\begin{array}{l}\text { Mississippi River near } \\
\text { St. Francisville, La. }\end{array}$ & 15,100 & 5,600 & 630 & 1,000 & 130 \\
\hline $5-10$ & $\begin{array}{l}\text { Mississippi River below } \\
\text { Belle Chasse, La. }\end{array}$ & 14,500 & 5,500 & 580 & 1,000 & 120 \\
\hline
\end{tabular}


Table 16. Organic-carbon and nitrogen contents of bed-sediment samples

[ND, not determined; $\%$, percent]

\begin{tabular}{|c|c|c|c|c|c|}
\hline Location & Date & River mile ${ }^{1}$ & $\begin{array}{c}\text { Organic } \\
\text { carbon } \\
(\%)\end{array}$ & $\begin{array}{c}\text { Nitrogen } \\
\text { (\%) }\end{array}$ & $\begin{array}{c}\text { Atomic C:N } \\
\text { ratio }\end{array}$ \\
\hline Pool 1 & $7-04-91$ & UM 848.0-849.2 & ND & 0.0 & ND \\
\hline Pig's Eye Slough & $10-08-91$ & UM 833.4 & 1.1 & 0.2 & 6.2 \\
\hline \multirow[t]{3}{*}{ Pool 2} & $7-07-91$ & UM816.1-821.1 & 1.2 & 0.1 & ${ }^{2} 13.6$ \\
\hline & 10-09-91 & & 1.4 & 0.1 & ND \\
\hline & 4-09-92 & & 1.6 & 0.1 & ND \\
\hline Pool 3 & $10-11-91$ & UM 797.3-798.1 & 1.9 & 0.2 & 11.8 \\
\hline Pool 4 (Upper Lake Pepin) & $10-14-91$ & UM 774.0-778.0 & 3.0 & 0.4 & 8.1 \\
\hline Pool 4 (Lower Lake Pepin) ${ }^{3}$ & $10-12-91$ & UM 768.0-772.0 & 3.5 & 0.4 & 9.7 \\
\hline Pool 5 & 7-11-91 & UM 739.8-744.7 & 1.0 & 0.1 & 11.0 \\
\hline Pool 5A & $7-11-91$ & UM 729.8 & 1.7 & 0.1 & 16.1 \\
\hline Pool $6^{3}$ & $4-13-92$ & UM 714.9-721.1 & 0.4 & 0.0 & 10.1 \\
\hline Pool 7 & 7-13-91 & UM 702.7 & 0.7 & 0.1 & 10.5 \\
\hline \multirow[t]{2}{*}{ Pool 8} & $7-14-91$ & UM 682.1-684.7 & 0.8 & 0.1 & 13.0 \\
\hline & $4-16-92$ & & 0.7 & 0.1 & ND \\
\hline Pool 9 & $10-19-91$ & UM 648.0-655.0 & 1.0 & 0.1 & 9.9 \\
\hline Pool 10 & 7-16-91 & UM 615.0-617.2 & 1.7 & 0.1 & 14.1 \\
\hline Pool 11 & $10-20-91$ & UM 585.1-591.9 & 0.9 & 0.1 & 9.3 \\
\hline Pool 12 & $4-18-92$ & UM 558.2-560.7 & 2.0 & 0.2 & 13.9 \\
\hline Pool $13^{3}$ & $10-21-91$ & UM 523.7-526.0 & 0.9 & 0.1 & 11.9 \\
\hline Pool 14 & 7-19-91 & UM 494.8-499.8 & 0.7 & 0.1 & 9.8 \\
\hline Pool $15^{3}$ & $4-20-92$ & UM 484.0-487.8 & 0.7 & 0.1 & 13.4 \\
\hline Pool 16 & $10-24-91$ & UM 457.0-458.7 & 0.9 & 0.1 & 10.3 \\
\hline Pool 18 & 4-22-92 & UM 411.8-414.5 & 1.6 & 0.1 & 14.5 \\
\hline Pool $19^{3}$ & $10-26-91$ & UM 366.3-371.6 & 1.2 & 0.2 & 7.5 \\
\hline Pool $20^{3}$ & $7-22-91$ & UM 344.2-346.6 & 0.6 & 0.0 & 14.2 \\
\hline Pool $21^{3}$ & $4-24-92$ & UM 326.6-331.4 & 0.5 & 0.0 & 18.7 \\
\hline Pool $22^{3}$ & $7-23-91$ & UM 303.0-306.0 & 0.4 & 0.1 & 6.7 \\
\hline Pool 24 & $10-29-91$ & UM 273.4-275.3 & 0.5 & 0.1 & 8.8 \\
\hline Pool 25 & 4-25-92 & UM 241.5-243.1 & 1.5 & 0.1 & 13.6 \\
\hline Pool 26 & $11-01-91$ & UM 206.1 & 1.5 & 0.2 & 11.7 \\
\hline $\begin{array}{l}\text { Illinois River near } \\
\text { Hardin, Ill. }\end{array}$ & $10-31-91$ & IL 21.8 & 1.6 & 0.2 & 12.4 \\
\hline $\begin{array}{l}\text { Missouri River near } \\
\text { St. Charles, Mo. }\end{array}$ & $4-29-92$ & MO 28.4 & 0.6 & 0.1 & 11.7 \\
\hline $\begin{array}{l}\text { Mississippi River near } \\
\text { Thebes, Ill. }\end{array}$ & $11-05-91$ & UM 44.0 & 1.5 & 0.2 & 7.5 \\
\hline $\begin{array}{l}\text { Mississippi River near } \\
\text { Greenville, Miss. }\end{array}$ & $11-08-91$ & LM 566.0 & 0.9 & 0.1 & 13.3 \\
\hline $\begin{array}{l}\text { Mississippi River near } \\
\text { St. Francisville, La. }\end{array}$ & $11-11-91$ & LM 266.4 & 1.3 & 0.1 & 11.9 \\
\hline
\end{tabular}


Table 16. Organic-carbon and nitrogen contents of bed-sediment samples --Continued

[ND, not determined; \%, percent]

\begin{tabular}{lccccc}
\cline { 2 - 4 } & & & Organic & Nitrogen & Atomic C:N \\
Location & Date & River mlie & carbon & $(\%)$ & ratio \\
& & & $(\%)$ & 0.1 & 12.3
\end{tabular}

Mississippi River near

Beile Chasse, La.

UM, Upper Mississippi River miles measured upstream from the confluence with Ohio River. IL, Illinois River miles measured

upstream from the confluence with Mississippi River (UM 217.9). MO, Missouri River miles measured upstream from the confluence

with Mississippi River (UM 195.3). LM, Lower Mississippi River miles measured upstream from Head of Passes, Louisiana.

${ }^{2}$ Data are the mean of three samples.

${ }^{3}$ Data are the mean of two replicates. 
Table 17. Organic-carbon and nitrogen percentages of bed-sediment samples and suspended silt and clay samples

\begin{tabular}{|c|c|c|c|c|}
\hline Dates & Sample and site & Organic carbon & Nitrogen & $\begin{array}{l}\text { Atomlc carbon } \\
\text { to nltrogen ratio }\end{array}$ \\
\hline \multirow[t]{2}{*}{ 10-11-91 } & Bed sediment from Pool 3 & 1.9 & 0.2 & 11.8 \\
\hline & $\begin{array}{l}\text { Silt and clay from Mississippi River at } \\
\text { Hastings, Minn. }{ }^{1}\end{array}$ & 5.5 & 0.9 & 7.5 \\
\hline \multirow[t]{2}{*}{$10-12,14-91$} & Bed sediment from Pool 4 (Lake Pepin) ${ }^{2}$ & 3.2 & 0.4 & 8.9 \\
\hline & $\begin{array}{l}\text { Silt and clay from Mississippi River near } \\
\text { Pepin, Wis. }{ }^{1}\end{array}$ & 10.0 & 1.7 & 7.3 \\
\hline \multirow[t]{2}{*}{ 4-13-92 } & Bed sediment from Pool 6 & 0.4 & 0.0 & 10.1 \\
\hline & $\begin{array}{l}\text { Silt and clay from Mississippi River at } \\
\text { Trempealeau, Wis. }{ }^{1}\end{array}$ & 8.8 & 1.4 & 7.5 \\
\hline \multirow[t]{2}{*}{ 10-19-91 } & Bed sediment from Pool 9 & 1.0 & 0.1 & 9.9 \\
\hline & $\begin{array}{l}\text { Silt and clay from Mississippi River below } \\
\text { Lock and Dam 9, Wis. }{ }^{1}\end{array}$ & 7.5 & 1.1 & 7.4 \\
\hline \multirow[t]{2}{*}{$10-21-91$} & Bed sediment from Pool 13 & 0.9 & 0.1 & 11.9 \\
\hline & $\begin{array}{l}\text { Silt and clay from Mississippi River at } \\
\text { Clinton, Iowa }\end{array}$ & 5.6 & 0.9 & 7.1 \\
\hline \multirow[t]{2}{*}{ 10-26-91 } & Bed sediment from Pool 19 & 1.2 & 0.2 & 7.5 \\
\hline & $\begin{array}{l}\text { Silt and clay from Mississippi River at } \\
\text { Keokuk, Iowa }{ }^{1}\end{array}$ & 4.8 & 0.8 & 8.0 \\
\hline \multirow[t]{2}{*}{$4-25-92$} & Bed sediment from Pool 25 & 1.5 & 0.1 & 13.6 \\
\hline & $\begin{array}{l}\text { Silt and clay from Mississippi River near } \\
\text { Winfield, Mo. }{ }^{1}\end{array}$ & 4.2 & 0.6 & 8.1 \\
\hline \multirow[t]{3}{*}{ 11-05-91 } & Bed sediment from Mississippi River at & 1.5 & 0.2 & 7.5 \\
\hline & Thebes, Ill. & 2.5 & 0.4 & 8.4 \\
\hline & $\begin{array}{l}\text { Silt and clay from Mississippi River at } \\
\text { Thebes, Ill. }{ }^{1}\end{array}$ & & & \\
\hline \multirow[t]{3}{*}{ 11-08-91 } & Bed sediment from Mississippi River near & 0.9 & 0.1 & 13.3 \\
\hline & Greenville, Miss. & 1.8 & 0.2 & 8.7 \\
\hline & $\begin{array}{l}\text { Silt and clay from Mississippi River below } \\
\text { Vicksburg, Mississippi }\end{array}$ & & & \\
\hline \multirow[t]{3}{*}{$11-11-91$} & Bed sediment from Mississippi River near & 1.3 & 0.1 & 11.9 \\
\hline & St. Francisville, La. & 2.0 & 0.3 & 9.6 \\
\hline & $\begin{array}{l}\text { Silt and clay from Mississippi River near } \\
\text { St. Francisville, La. }\end{array}$ & & & \\
\hline \multirow[t]{3}{*}{ 11-13-91 } & Bed sediment from Mississippi River below & 0.8 & 0.1 & 12.3 \\
\hline & Belle Chasse, La. ${ }^{1}$ & 1.9 & 0.2 & 9.8 \\
\hline & $\begin{array}{l}\text { Silt and clay from Mississippi River below } \\
\text { Belle Chasse, La. }{ }^{1}\end{array}$ & & & \\
\hline
\end{tabular}

sample was collected.

${ }^{2}$ Values are means of Upper and Lower Lake Pepin samples. 
The C:N ratios of organic matter in the bed sediment is normally 3-5 units greater than the C:N ratios of suspended silts and clay because diagenetic processes normally mineralize nitrogen faster than carbon when suspended sediments are deposited in bed sediments (Ishiwatari, 1985). However, there is little difference in the C:N ratios of the bed sediment and suspended silt and clay at the Keokuk and Thebes sites, and only a small difference at Lake Pepin. These small differences may indicate particulate nitrogen is being input into the bed sediments faster than diagenetic processes degrade the nitrogen. This situation may indicate problems with sediment quality at these sites, especially if anaerobic conditions in the bed sediment produce ammonia that is toxic to organisms that live in bed sediments. Pool 19 near Keokuk is a repository for sediments contaminated with nitrogenous wastes from the Rock Island, Ill., Moline, Ill., Davenport, Iowa, and Bettendorf, Iowa, metropolitan region; it also receives agricultural nitrogenous inputs from the lowa River. The Thebes site receives nitrogenous wastes from the St. Louis metropolitan region, and Lake Pepin receives nitrogenous wastes from Minneapolis-St. Paul region.

The suspended silts and clays become progressively depleted in organic carbon and nitrogen downstream. This depletion may represent both instream degradation of organic matter in the silt and clay fractions as they move downriver and dilution by input of silt and clay low in organic carbon by tributaries in the Lower Mississippi River. Increases in the $\mathrm{C}: \mathrm{N}$ ratio of the silt and clay fraction in the Lower Mississippi River may indicate instream degradation as the sediments are transported downstream.

\section{SEASONAL VARIATION}

\section{Dissolved Organic Matter}

The dissolved organic-carbon data for the upriver of the June-August 1991 (summer), September-November (fall), and March-May 1992 (spring) sampling cruises are listed in tables 1, 6, and 11 and are shown as a function of river mile in figure 2 to assess differences in DOC between summer, fall, and spring. The water-temperature data (Moody, 1994) are also plotted in this figure to show potential differences in biological processes that generally are proportional to temperature.

The DOC data in figure 2 are nearly identical for all three cruises for the Mississippi River below the Ohio River. Upriver from the Missouri River confluence, the data begin to diverge, and marked differences are present upriver from the Des Moines River confluence. The data in table 2 indicate that there was instream loss of DOC in the Upper Mississippi River during the summer downriver cruise, but similar losses were not apparent in the data for the spring and fall downriver cruises (tables 7 and 12).

A companion study to this report on the Lower Mississippi River (Leenheer and others, 1995) used ${ }^{1} \mathrm{H}-\mathrm{NMR}$ spectroscopy to qualitatively assess instream degradation of DOC. A sample ${ }^{1} \mathrm{H}-\mathrm{NMR}$ spectrum of DOC isolated from the Mississippi River at Hastings, Minn., during the spring sampling cruise is shown in figure 3. In the Lower Mississippi River study, the height ratio of peak 2 to peak 1 (spectral peaks are numbered in fig. 3) was inversely related to the degree of degradation of DOC, and the ratio of peak 5 to peak 1 was directly related to the relative aromatic carbon content of the DOC. These peak height ratios for the fall and spring sampling cruises are presented in table 18.

The ratio of peaks 2:1 data in table 18 indicate that the DOC generally (excepting the sample at St. Anthony Falls) was more degraded during the fall cruise than during the spring cruise. From Lock and Dam 9 downriver, there was more degradation of DOC in the downriver direction during the fall cruise than during the spring cruise. These findings are not surprising when one considers the stream temperature profiles in figure 2. The warmer stream temperatures during the fall cruise would promote greater biological activity, and river temperature rose in a downriver direction for both spring and fall cruises.

The relative aromatic carbon content (ratio of peaks 5:1) was similar during the fall and spring cruises. Sites where there were low suspended-sediment concentrations appear to have the greatest aromatic carbon contents. Sedimentary material has been found to adsorb and act as a solubility control on aromatic humic substances in certain environments (McKnight and others, 1992). The question of whether DOC degrades instream is important

with regard to contaminant transport and release. In the summer when water temperatures are near $25^{\circ} \mathrm{C}$, instream degradation of DOC is hypothesized from the data in table 18 to be a significant process in the Upper Mississippi 

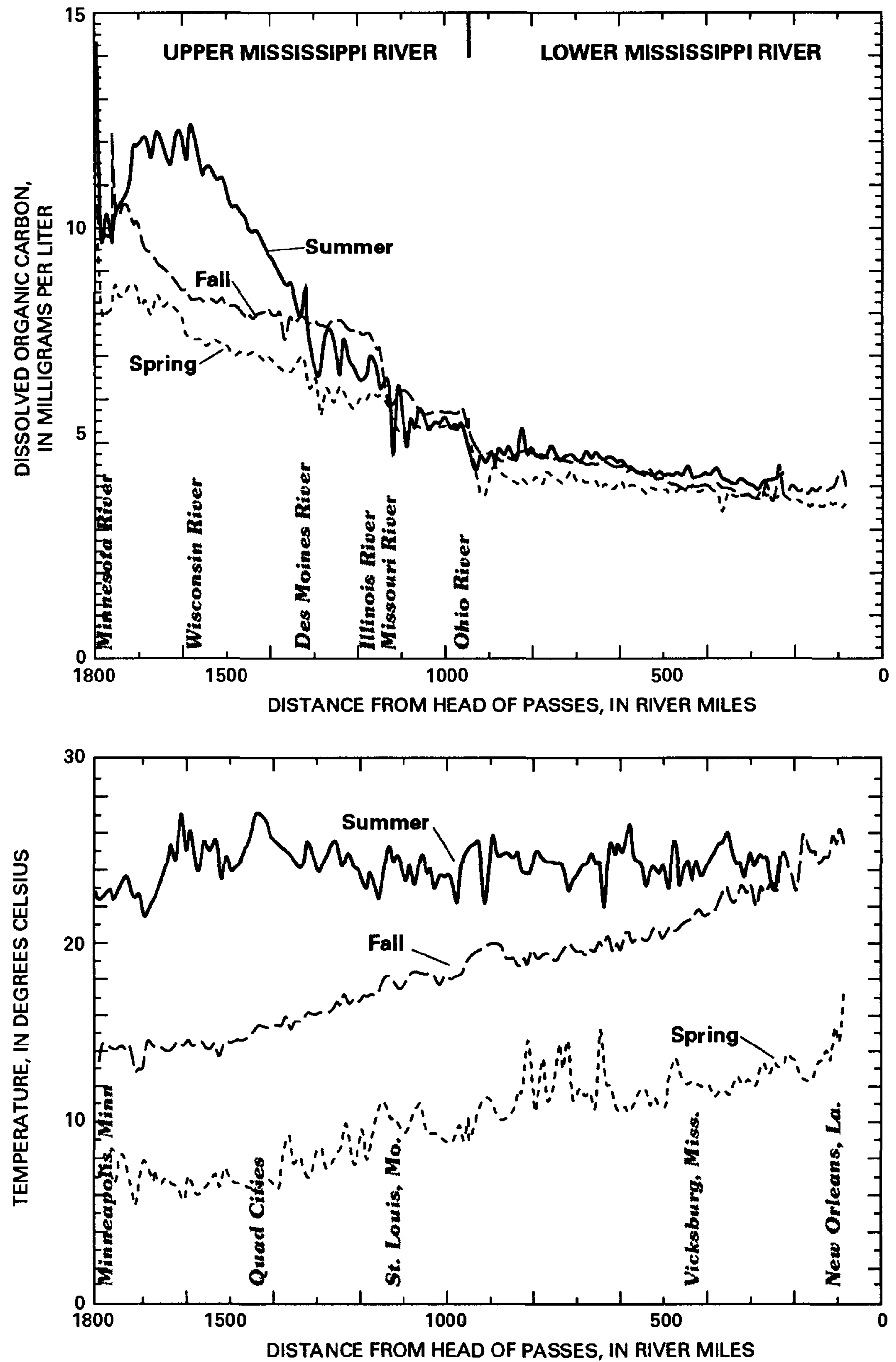

Figure 2.--Graphs showing dissolved organic-carbon concentration and water temperature (Moody, 1994) for the Mississippi River as a function of river miles upstream from Head of Passes, La., for the summer, fall, and spring. This does not show the true distance between samples in the water which is listed in a report by Moody (1994). 


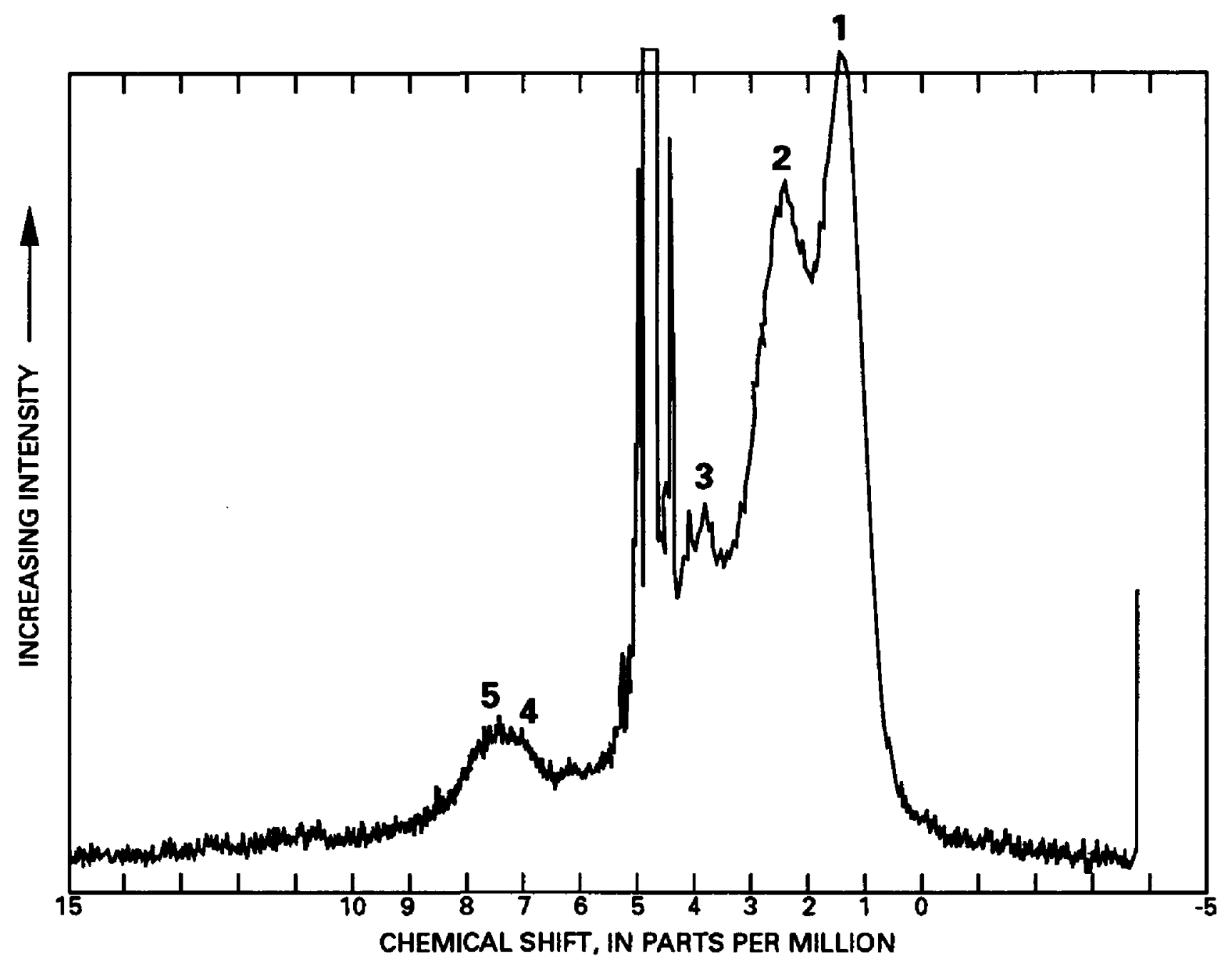

Figure 3.--1 $\mathrm{H}$-nuclear magnetic resonance (NMR) spectrum of dissolved organic matter isolated from the Mississippi River at Hastings, Minn., during the March-May 1992 (spring) sampling cruise. (see text for description of numbers on spectral peaks). 
Table 18. Peak height ratios for ${ }^{1} \mathrm{H}$-NMR data for dissolved organic-carbon samples collected during the SeptemberNovember 1991 (fall) and March-May 1992 (spring) sampling cruises

[ND, not determined]

\begin{tabular}{|c|c|c|c|c|}
\hline \multirow{3}{*}{ Site name } & \multicolumn{2}{|c|}{$\begin{array}{c}\text { September-November } 1991 \\
\text { cruise }\end{array}$} & \multicolumn{2}{|c|}{$\begin{array}{l}\text { March-May } 1992 \\
\text { cruise }\end{array}$} \\
\hline & Peaks & Peaks & Peaks & Peaks \\
\hline & 2:1 & $5: 1$ & 2:1 & $5: 1$ \\
\hline Mississippi River above St. Anthony Falls, Minn. & 0.66 & $\overline{0.23}$ & 1.08 & 0.22 \\
\hline Minnesota River at River Mile 3.5, Minn. & 0.66 & 0.10 & 0.77 & 0.13 \\
\hline Mississippi River at Hastings, Minn. & 0.76 & 0.14 & 0.83 & 0.14 \\
\hline St. Croix River at River Mile 0.5 , Wis. & ND & ND & 0.86 & 0.18 \\
\hline Mississippi River near Pepin, Wis. & 0.77 & 0.18 & 0.86 & 0.18 \\
\hline Mississippi River at Trempealeau, Wis. & 0.83 & 0.19 & ND & ND \\
\hline Mississippi River below Lock and Dam 9, Wis. & 0.88 & 0.23 & 0.84 & 0.19 \\
\hline Mississippi River at Clinton, Iowa & 0.75 & 0.17 & ND & ND \\
\hline Mississippi River at Keokuk, lowa & 0.69 & 0.14 & 0.83 & 0.19 \\
\hline Mississippi River near Winfield, Mo. & 0.79 & 0.16 & ND & ND \\
\hline Illinois River at Hardin, Ill. & 0.62 & 0.13 & ND & ND \\
\hline Missouri River at St. Charles, Mo. & 0.62 & 0.13 & 0.83 & 0.16 \\
\hline Mississippi River at Thebes, Ill. & 0.62 & 0.11 & 0.79 & 0.17 \\
\hline Ohio River at Olmsted, Ill. & 0.67 & 0.18 & 0.74 & 0.16 \\
\hline Mississippi River below Vicksburg, Miss. & 0.61 & 0.15 & 0.71 & 0.14 \\
\hline Mississippi River near St. Francisville, La. & 0.61 & 0.15 & 0.76 & 0.14 \\
\hline Mississippi River below Belle Chasse, La. & ND & ND & 0.67 & 0.15 \\
\hline
\end{tabular}


River. In the spring (and most likely the winter), instream degradation is minor in the Upper Mississippi River; these degradation processes are probably more important downstream where water temperatures are warmer.

Although this report presents evidence for instream degradation of DOC, examination of the spatial profiles of DOC during the three sampling cruises and examination of all relevant data presented in this report indicate that dilution of the Mississippi River by lower DOC water from southern tributaries is the major factor in causing the decrease in DOC concentrations from upstream to downstream. The reason for the lower DOC levels in the southern Mississippi River tributaries is probably the combined result of increased biodegradation rates in the soils caused by the higher annual temperatures in the South then in the North and a difference in geology and soil characteristics. The highly weathered and oxidized soils of the South are much better adsorbents for DOC (on iron and aluminum sequioxide coatings) than are the relatively young glaciated soils of the North. The Northern States also have extensive sandy glacial outwash deposits, and these sandy soils have very little affinity for dissolved organic carbon. The "black-water" tributaries of the Mississippi (Black and St. Croix Rivers) arise in the sandy-soil regions of northern Wisconsin.

\section{Organic Matter in Suspended-Sediment Fractions}

Seasonal effects are more difficult to interpret for the suspended-sediment fractions. Hydrologic processes are a larger factor in controlling suspended-sediment concentrations and composition than are biological processes that are dependent on temperature. The atomic C:N ratio of suspended sediment was found to have a seasonal dependence. In the St. Lawrence River, lower C:N ratios during the summer occur because of growth of algae that are rich in nitrogen (Telang and others, 1991). However, even the lowest C:N values in the St. Lawrence River were above typical values found for suspended sediment in the Upper Mississippi River. The C:N ratios for suspended silt and clay in the Upper Mississippi River were even lower during the low-water conditions of the fall and spring cruises than during the summer cruise when algae growth should be a significant factor.

In short, the Upper Mississippi River does not show normal seasonal geochemical trends with respect to $\mathrm{C}: \mathrm{N}$ ratios of suspended sediment. A likely reason is that massive allochthonous inputs of sedimentary nitrogen from agricultural sources in Illinois, lowa, and Minnesota dominate the more normal seasonal trends that were observed in the St. Lawrence River.

\section{CONCLUSIONS}

The four major conclusions based on the study described in this report are as follows:

1. Sediments in the Upper Mississippi River have large nitrogen contents. The suspended silts and clays in particular have nitrogen percentages that are 1.5 to 2.0 times those measured for natural uncontaminated sediments. These sediments probably are from areas of intensive agriculture with associated nitrogen fertilization of soils in the Upper Midwest. The likely consequence of long-term inputs of high nitrogen sediments into the navigation pools of the Upper Mississippi River is the generation of toxic levels ammonia in bed sediments during periods of high microbiological activity.

2. Colloidal organic matter (and possibly associated contaminants) is transported in a physically and chemically conservative manner in the Upper Mississippi River. Transport calculations indicate very little of the colloidal organic matter is being lost in the deeper navigation pools (Lake Pepin and Pool 19) that serve as sediment traps. Thus, colloid-bound contaminants may be transported conservatively in the Upper Mississippi River if the biological rate of colloid degradation is slow relative to colloid transport rates.

3. The large organic-carbon content of colloids in the Upper Mississippi River enhances the sorption of nonpolar organic contaminants. Organic-carbon contents of the colloid fractions in the Upper Mississippi River were 2 to 3 times the contents in the Lower Mississippi River. Contaminants such as PCBs were found to partion into the organic matter of these colloids (Rostad and others, 1994) and presumably are conservatively transported on the colloids.

4. Dissolved, suspended silt and clay, and colloidal organic matter in the Mississippi River decreases from Minneapolis-St. Paul to New Orleans. This decrease is primarily caused by dilution from tributaries that are lower in dissolved and suspended organic-matter concentrations in the Southern United States. However, changes in 
organic-matter composition and cumulative transport calculations indicate that instream loss of dissolved and colloidal organic matter occurs during transport from north to south. This loss of organic matter is of concern because associated contaminants may be released during the process of degradation. Thus, contaminants bound in the Upper Mississippi River may be transported and released in the Lower Mississippi River.

\section{REFERENCES}

Aiken, G.R., 1992, Chloride interference in the analysis of dissolved organic carbon by the wet oxidation method: Environmental Science and Technology, v. 26, p. 2435-2439.

Frenkel, H., Fey, M.V., and Levy, G.J., 1992, Organic and inorganic anion effects on reference and soil clay critical flocculation concentration: Journal Soil Science Society of America, v. 56, p. 1762-1766.

Hedges, J.I., and Farrington, J., 1993, Measurement of dissolved organic carbon and nitrogen in natural waters - Workshop report: Marine Chemistry, v. 41, p. 5-10.

Ishiwatari, R., 1985, Geochemistry of humic substances in lake sediments in Aiken, G. R., McKnight, D. M., Wershaw, R. L., and MacCarthy, P., eds. Humic substances in soil, sediment, and water-Geochemistry, isolation, and characterization: New York, Wiley, p. 147-180.

Leenheer, J.A., 1991, Organic substance structures that facilitate contaminant transport and transformations in aquatic sediments, in Baker, R.A. ed. Organic substances and sediments in water, volume 1. Humics and Soils: Chelsea, Mich., Lewis Publishers, p. 3-21.

Leenheer, J.A., Meade, R.H., Taylor, H.E., and Pereira, W.E., 1989, Sampling, fractionation and dewatering of suspended sediment from the Mississippi River for geochemical and trace-contaminant analysis, in Mallard, G.E., and Ragone, S.E., eds. U.S. Geological Survey Toxic Substances Hydrology Program-Proceedings of the technical meeting, Phoenix, Arizona, September 26-30, 1988: U.S. Geological Survey Water-Resources Investigations Report 88-4220. p. $501-511$.

Leenheer, J.A., Noyes, T.I., and Brown, P.A., 1995, Data on natural organic substances in dissolved, colloidal, and suspended silt phases in the Mississippi River and its major tributaries, 1987-1990: Water-Resources Investigations Report 93-4204, $71 \mathrm{p}$.

McKnight, D. M., Bencala, K. E., Zellweger, G. W., Aiken, G. R., Feder, G.L., and Thorn, K. A., 1992, Sorption of dissolved organic carbon by hydrous aluminum and iron oxides occurring at the confluence of Deer Creek with the Snake River, Summit County, Colorado: Environmental Science and Technology, v. 26, 1388-1396.

Moody, J.A., 1994, Chemical data for water samples collected during four upriver cruises of the Mississippi River between New Orleans, Louisiana, and Minneapolis, Minnesota, May 1990-April 1992: U.S. Geological Survey Open-File Report 94523.

Moody, J.A. and Meade, R.H., 1992, Hydrologic and sedimentologic data collected during three cruises at low water on the Mississippi River and some of its tributaries, July 1987-June 1988. U.S. Geological Survey Open-File Report 91-485, $143 \mathrm{p}$.

Moody, J.A. and Meade, R.H., 1994a, Evaluation of the method of collecting suspended sediment from large rivers by discharge-weighted pumping and separating it by continuous-flow centrifugation: Hydrological Process, v. 8, 513-530.

Moody, J.A. and Meade, R.H., 1994b, Hydrologic and sedimentologic data collected during three cruises on the Mississippi River and some of its tributaries from Minneapolis, Minnesota, to New Orleans, Louisiana, July 1991-June 1992: U.S. Geological Survey Open-File Report 94-474.

Rostad, C.E., Monsterleet, S.G., Bishop, L.M., and Ellis, G.S., 1994, Polychlorinated biphenyls associated with suspended silt and clay and colloid from the Mississippi River and some of its tributaries, July 1991 to November, 1991: U.S. Geological Survey Open-File Report 94-484, in press.

Telang, S.A., Pocklington, R., Naidu, A.S., Romankevich, E.A., Gitelson, I.I., and Gladyshev, M.I., 1991, Carbon and mineral transport in major North American, Russian Arctic, and Siberian rivers-The St. Lawrence, the Mackenzie, the Yukon, the Arctic Alaskan River, the Arctic Basin Rivers in the Soviet Union, and the Yenisei in Degens, E.T., Kempe, S., and Richey, J.E., eds., Biogeochemistry of major world rivers, SCOPE 42: New York, Wiley, p. 75-104. 